AL.2.2007.214
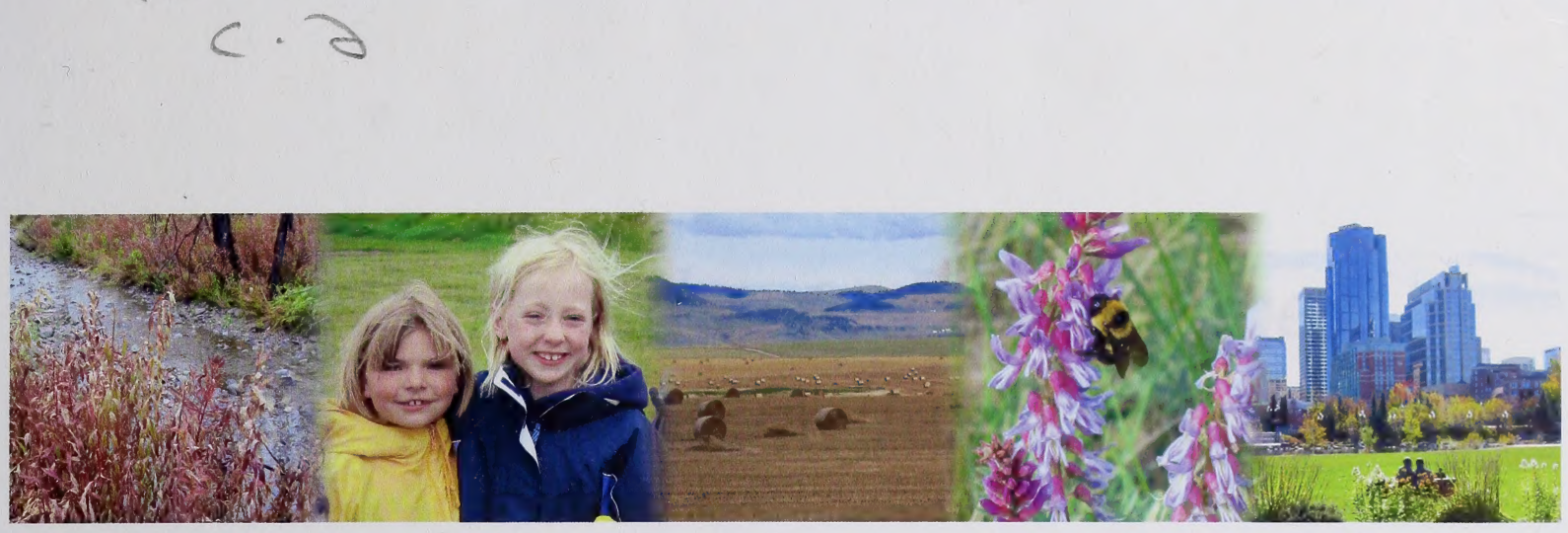

Southern Alberta Landscapes MEETING THE CHALLENGES AHEAD $\gg$

\title{
An Overview of Public Issues
}

\author{
Prepared for \\ Alberta Environment \\ By Kim Lalonde Environmental Consulting \\ February 2006
}

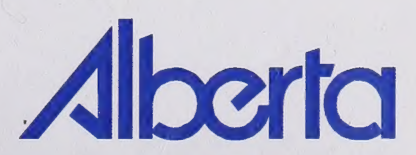


Digitized by the Internet Archive in 2016 


\section{Southern Alberta Landscapes: Meeting the Challenges Ahead}

\section{An Overview of Public Issues}

Prepared for

Alberta Environment

By Kim Lalonde Environmental Consulting

February 2006 


\section{Southern Alberta Landscapes: Meeting the Challenges Ahead}

\section{An Overview of Public Issues}




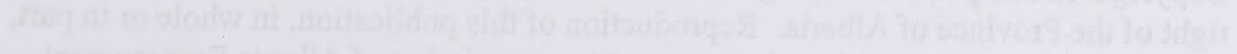

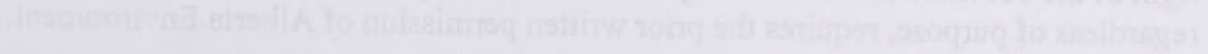


Pub. No. I-013

ISBN: 0-7785-5065-6 (Print version)

ISBN: 0-7785-5066-4 (Online version)

Website: www.gov.ab.ca/env/

Disclaimer: The contents of this document have been prepared with funds from Alberta Environment but do not necessarily reflect the Ministry's views or policies. Any mention of trade names or commercial products does not constitute an endorsement or recommendation for use.

Any comments, questions or suggestions on the content of this document may be directed to:

Regional Environmental Management

Alberta Environment

3rd Floor, Deerfoot Square

2938 - 11 Street N. E.

Calgary, Alberta T2E 7L7

Ph: (403) 297-7602

Fx: (403) 297-6069

Additional print copies of this document are available from:

Information Centre

Alberta Environment

Main Floor, Oxbridge Place

9820-106 Street

Edmonton, Alberta T5K 2J6

$\mathrm{Ph}:$ (780) $427-2700$

Fx: (780) 422-4086

Outside of Edmonton dial 310-0000 for toll-free connection

Email: env.infocent@gov.ab.ca

Copyright in this publication, regardless of format, belongs to Her Majesty the Queen in right of the Province of Alberta. Reproduction of this publication, in whole or in part, regardless of purpose, requires the prior written permission of Alberta Environment.

(c) Her Majesty the Queen in right of the Province of Alberta, 2006. 


\section{CONTENTS}

$\underline{\text { Page }}$

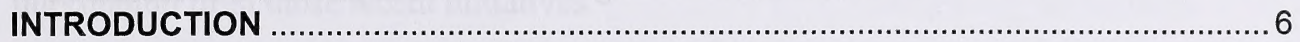

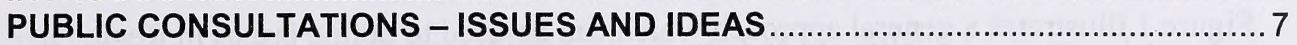

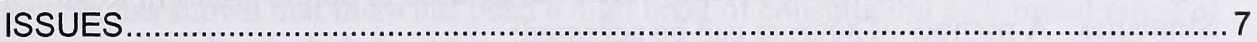

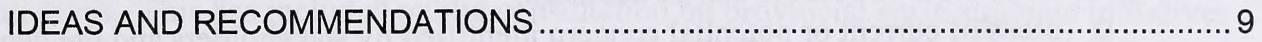

CONCLUSIONS

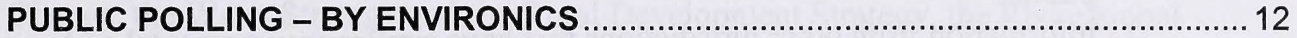

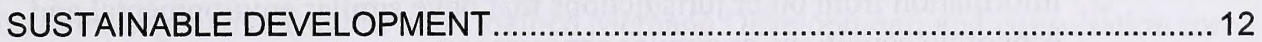

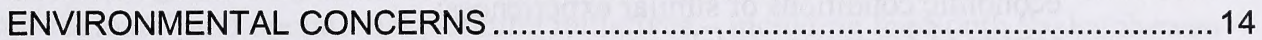

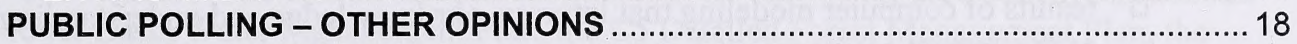

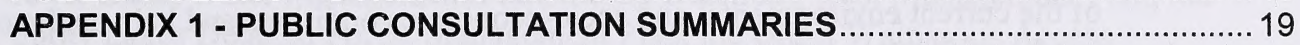

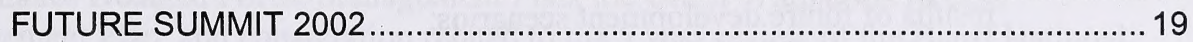

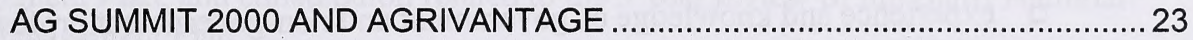

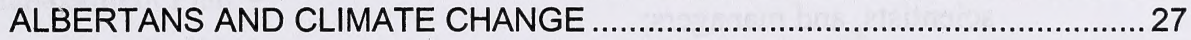

WATER FOR LIFE: ALBERTA'S WATER STRATEGY ……....................... 30

SOUTH SASKATCHEWAN RIVER BASIN WATER MANAGEMENT PLAN.....36

RURAL DEVELOPMENT STRATEGY ................................................... 39

C5 DETAILED FOREST MANAGEMENT PLAN ……...............................42

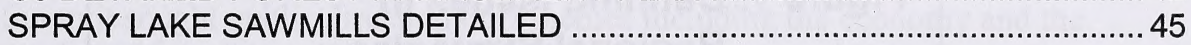

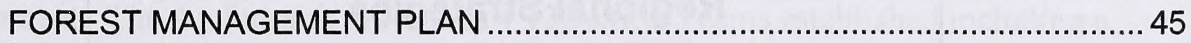

RECREATION CORRIDORS LEGISLATIVE REVIEW …........................... 47

GHOST RIVER / WAIPAROUS ACCESS MANAGEMENT PLAN ….................50

BANFF NATIONAL PARK MANAGEMENT PLAN REVIEW ..........................5

COALBED METHANE / NATURAL GAS IN COAL CONSULTATIONS .............54

APPENDIX 2 - SCAN OF ENVIRONICS POLLING INFORMATION ….......................56

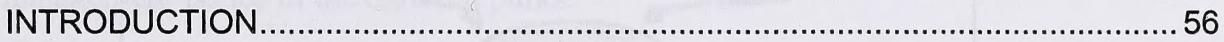

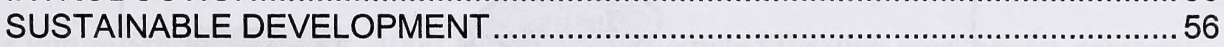

SUPPORT FOR SUSTAINABLE DEVELOPMENT ……...........................56

THE ENVIRONMENT AND THE ECONOMY …….......................................5

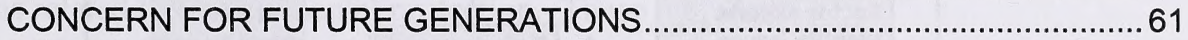

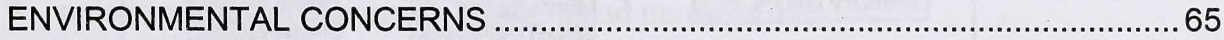

RANKING OF ENVIRONMENTAL CONCERNS ……...............................6

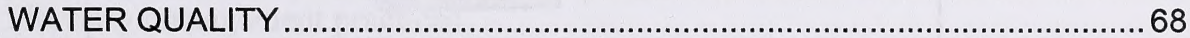

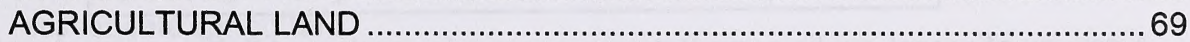

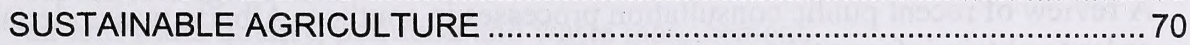

LOSS OF SPECIES AND BIODIVERSITY ……….......................................

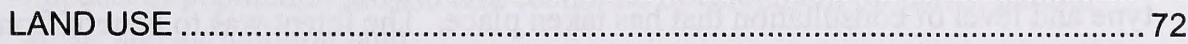




\section{INTRODUCTION}

The original Terms of Reference for the Southern Alberta Sustainability Strategy (SASS) included three objectives, the first of which was to identify the key issues related to sustainable resource and environmental management and their priority for resolution.

Figure 1 illustrates a general approach which can be used to define issues in Regional Strategies. A number of sources can be accessed:

a areas of current or potential concern identified by stakeholders and the general public;

a information from other jurisdictions that have similar environmental and economic conditions or similar experiences;

a results of computer modeling that improve our knowledge and understanding of the current environmental and socio-economic conditions and help analyze results of future development scenarios;

a experience and knowledge of government and non-government professionals, scientists, and managers;

a gaps or conflicts in government policies and strategies when applied to the regional scale;

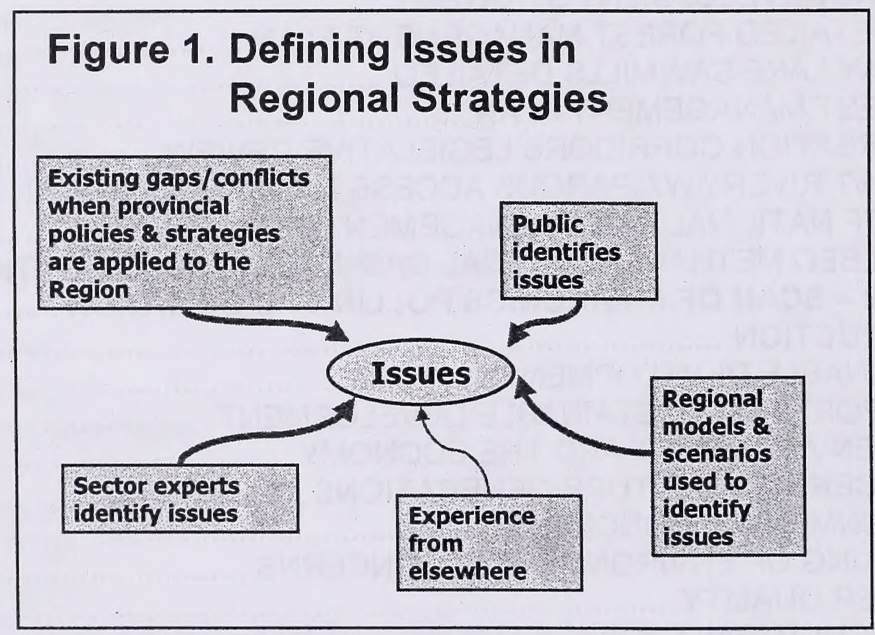

A review of recent public consultation processes in southern Alberta was undertaken in order to obtain information about areas of current or potential concern and to assess the type and level of consultation that has taken place. The intent was to benefit from the public consultation and discussion work already done by government, non-government organizations and the public related to other strategic and planning initiatives in the region. Additional work was also done to determine if concerns identified in southern Alberta were reflected in opinions related to sustainable development provincially and nationally.

This report includes summaries of the findings from the review and detailed information for further reference in the appendices. 


\section{PUBLIC CONSULTATIONS - ISSUES AND IDEAS}

A scan of recent public consultation processes was undertaken in order to assess the type and level of consultation that has taken place in southern Alberta, and to compile information from those recent initiatives.

This scan has shown that there has been a high level of consultation on a broad range of initiatives. This has included public consultation on provincial scale strategic initiatives and policy including the Future Summit 2002, the Ag Summit, Albertans and Climate Change, the Water Strategy and the Rural Development Strategy, the Recreational Corridors Legislative Review and Coalbed Methane Development; and consultation for "sub-regional" and operational planning initiatives - including the South Saskatchewan River Basin Water Management Plan, the C5 Detailed Forest Management Plan, the Spray Lakes Detailed Forest Management Plan, the Ghost Waiparous Access Management Plan, and consultation related to the 5 year review of the Banff National Park Management Plan.

\section{ISSUES}

There has been a broad range of topics discussed, mirroring the varying initiatives. The Future Summit sought public direction on 7 themes including the economy and the environment. The Ag Summit process saw 13 Action Teams established including a Land Use Core Action Team and an Environmental Stewardship Action Team. There have been strategic discussions about climate change, water management and the future of rural communities in the province. There have been, and will continue to be, more specific discussions about forestry management, water management, access management and management issues in the national parks.

In the Future Summit process, 4000 Albertans participated through workbooks, regional forums and MLA meetings for constituents. Albertans identified a wide range of concerns related to environmental protection. These included:

- preservation and expansion of parks and natural areas

- water quality, treatment, availability and supply

- forestry management practices

- sustainable agriculture

- air and water quality, pollution and waste management

- impacts of population growth and economic development on parks, natural areas, and agricultural land

Through the Ag Summit process, the Land Use Core Action Team summarized land use issues in Alberta, including:

- continued consumption of, and competition for, land by all sectors of the economy; and escalating land use conflicts

- loss of high quality soils - a finite resource

- concerns regarding lack of vision, policies and effective decision making

- constraints related to data sharing and the need for improved communication and awareness 
Through the Water Strategy process, participants confirmed five top challenges for water management:

- pollution and contamination of surface water and groundwater

- access to safe drinking water

- the need for a better public understanding of water systems and wise water use

- industrial and agricultural growth resulting in increased demand for water in places where water is not always plentiful

- water becoming an increasingly scarce resource in Alberta

The government undertook the Recreation Corridors Legislation Review because "there needs to be a balance of the rights and responsibilities of all stakeholders involved in recreational corridor use." And the Alberta government is reviewing the regulations that govern natural gas in coal development to ensure that they continue to balance economic benefits for Albertans with protecting the land, air and water resources.

The issues being considered in the South Saskatchewan River Basin Water Management Plan process arose as the result of questions about the availability of water in the basin. The terms of reference for the C5 Forest Management Plan advises that "public pressure, recent EUB hearings and other large scale planning reviews have indicated that new approaches and a comprehensive land management strategy that minimizes impacts and ensures sustainability must be developed and implemented". The Spray Lakes Sawmill initiated a public consultation process to provide stakeholders and the general public an opportunity to review and provide input into their Detailed Forest Management Plan for the area.

The Ghost River - Waiparous Access Management Plan is intended to address a range of issues including conflicts between uses of the area, options for management and enforcement and concerns about restrictions on use, and concerns related to impacts on the environment. The government undertook the Recreation Corridors Legislation Review because "there needs to be a balance of the rights and responsibilities of all stakeholders involved in recreational corridor use." The Banff National Park Management Plan was approved in 1997 and the Waterton National Park Management Plan was reviewed and updated in 2000. Both are 15-year documents that must be reviewed every 5 years. Parks Canada has processes in place to ensure that there are opportunities for public involvement in discussions on issues related to the Management Plans.

In reviewing the information from the various initiatives, some common themes emerge. There are concerns related to increasing demands on resources and conflicts in the use of resources. There are concerns about ecosystem health and cumulative effects. And there is a growing recognition that population growth is an important factor in increasing pressures on our resources and ecosystems. 


\section{IDEAS AND RECOMMENDATIONS}

While issues were identified, another focus in the consultations was discussion about options and approaches that could be taken and the development of recommendations. Just as there were common themes about the nature of the issues, there were some common themes in the ideas and recommendations.

Shared Vision - Visions for the future and goals were discussed in the strategic consultation processes. They reflect support for a sustainable future.

When Albertans think about the future, they would like to see a clean, healthy natural environment where economic development and environmental protection are carefully balanced.

The Future Summit

The vision is the creation of a collaborative, competitive, positive business climate supporting the continued growth of a profitable, environmentally sustainable agriculture and food industry in Alberta.

The Ag Summit

Strategic Planning and Policy Frameworks - There was general support for the need to take long term and strategic planning approaches to ensure the province's continued prosperity into the future.

Create a comprehensive, long-term economic plan that extends over a number of business and political cycles and addresses infrastructure, fiscal policy and environmental needs.

The Future Summit (Economy)

Develop a long term environmental protection plan that is well researched, proactive and founded on solid science. The plan must include sustainable strategies, enforceable standards and measurable results. Governments, businesses, communities and individual citizens should be partners in the development and implementation of this plan.

The Future Summit (Environment)

It is recommended that the province and municipalities, both urban and rural, form partnerships with all industry sectors and the public, regarding the development of a long term sustainable land use policy and regulation framework. The Ag Summit

The provincial government is already doing much to manage water quality effectively, but a strategic approach will be needed in the future.

The Water Strategy 
Planning - Planning is seen as an important way to understand and address resource conflicts and other challenges.

Promote regional planning initiatives that safeguard Alberta's land and water resources, protect ecologically sensitive areas and preserve green space while fostering environmentally friendly economic development.

The Future Summit (Environment)

There should be significant emphasis on watershed planning and management The Water Strategy

Champion environmentally sustainable planning and integrated multi-stakeholder decision making for water, land, mineral, energy and other renewable resources.

Rural Development Strategy

Regulatory Frameworks - The need for clear regulatory frameworks with effective monitoring and enforcement was recognized.

Many Albertans felt a regulatory approach was needed to ensure good environmental performance - particularly by industry - they proposed strong environmental legislation, standards and monitoring, along with strong or stronger enforcement and penalities.

The Future Summit (Environment)

Near universal agreement on the importance of regulation - important to have a regulatory backstop.

Climate Change Strategy

The provincial government should continue to prevent pollution and contamination of water, improved regulations, monitoring and enforcement are recommended.

The Water Strategy

Range of Tools - And beyond regulatory frameworks, there was broad support for the development and use of a full range of tools.

Implement a program of incentives to reward and encourage good environmental behaviour.

The Future Summit (Environment)

Research and Innovation - research and innovation were recognized as critical to the future success of the province.

Create and sustain a culture of entrepreneurship and innovation.

The Future Summit (Economy) 
Invest more in research and development for alternative energy sources and clean technologies.

Climate Change Strategy

Education and Stewardship - There was recognition of the need for shared responsibility, and recognition of the importance of education in building environmental awareness and support for shared responsibility, and in supporting informed individual decision-making.

Albertans believe that education is key to environmental awareness.

The Future Summit (Environment)

There should be significant emphasis on education and involvement of both stakeholders and the public in water management planning and implementation.

The Water Strategy

\section{CONCLUSIONS}

A wealth of information on concerns and ideas is available through the extensive public consultation work that has been undertaken in the Region related to sustainable resource and environmental management. SASS, as a regional strategy, can pull together these concerns and ideas and provide a comprehensive and integrated approach to sustainable resource and environmental management for the Region. This will fill the gap between provincial policies, programs and strategies and the more detailed "sub-regional" and local initiatives. And it provides an approach that considers all economic sectors and environmental media. More detailed information on the public consultation initiatives can be found in Appendix 1 .

Albertans "recognize that the issues that face the province are inextricably linked and that strategies for the future cannot be developed in isolation. Rather, an integrated, cross-sectoral approach is required."

Message from the Co-Chairs of the Future Summit 


\section{PUBLIC POLLING - BY ENVIRONICS}

Environics surveys Canadians on environmental issues on a regular basis over the year, with results published in the Environmental Monitor. A scan of the Environmental Monitor reports from 1989 to 2002 was undertaken to identify if there had been any significant changes in public opinion over a period of about one decade. An overview of the results of this scan follows. The full report can be found in Appendix 2.

\section{SUSTAINABLE DEVELOPMENT}

Environics has asked questions related to sustainable development both directly and indirectly in the following ways:

- Support for Sustainable Development

Environics asked Canadians in 1989 if sustainable development - "a new term that means developing our economy in a way that minimizes damage of the environment, so that it is capable of supporting our economy and society over the long term" - should be a priority. Questions were again asked in 1990, 1992 and 1995.

- The Environment and the Economy

Over the period from 1989 to 2002, Environics asked a number of questions about the relationship between the environment and the economy that provide some insights. In 1990 and 1991, questions sought indications of public opinion about the consideration that should be the most influential factor in the creation of an overall economic strategy for Canada. Over the period of 1994 to 2002, Canadians were asked about "trade-offs" between the environment and the economy. Canadians have been asked about the impact of environmental cleanup and protection on the economy. They were also asked about the potential benefit of environmental protection to the economy and about the possible benefits of environmental clean-up. In 1990, 1991 and 1992, Canadians were asked questions about the impact of clean-up and protection of the environment on levels of unemployment. In January 1996, the focus of the question was protection of the environment versus prices and jobs.

- Concern for Future Generations

Environics asked a number of questions relating to future generations that can be linked to Canadians' views about long term sustainability. Canadians have been asked questions about the priority of future generations over the present generation, nature's value for today and for the future, the greatest threat to future generations and the effects of environmental pollution on children and future generations.

A number of general conclusions can be made based on a review of the Environics results. 
- Strong support for the concept of sustainable development has been consistent over the period from 1989 to 2002 . This support has been there from the time the term "sustainable development" was coined, even though it was not widely understood or used. This reflects a strong Canadian belief in the principles underlying what we call sustainable development.

In 1992, only $23 \%$ of Canadians (21\% of Albertans) replied that they had heard of sustainable development. However, when it was described, $72 \%$ of Canadians (72\% of Albertans) responded that it should be a priority for Canada.

Environics

- When looking at the questions posed and the responses from Canadians, there appears to have been a shift from looking at the environment and the economy as an either/or tradeoff, to the view that environmental and economic health are complementary.

In 2002, Environics concluded "that the belief that economic and environmental health are complementary is more widely held than the belief that the opposing view that an economic tradeoff is inherent in environmental protection."

- Canadians have consistently believed that clean-up and protection of the environment will contribute to economic growth and only a minority expressed the opinion that protecting the environment would increase unemployment.

In 2000, more than eight in ten ( $83 \%$, Albertans $73 \%)$ strongly or somewhat agreed that the clean-up and protection of the environment, would, in itself, contribute to the growth of our economy. "These findings have not varied significantly since Environics first asked this question in 1988".

- Canadians are concerned about future generations and the impact that our decisions and actions today will have on the future.

In 1994, over eight in ten Canadians somewhat or strongly disagreed with the statement, "our first priority should be to meet the needs of the present generation and let future generations look after themselves." Canadians overwhelmingly reject the idea of placing our needs before those of future generations." In the years 2000 and 2002, 74\% and $76 \%$ of Canadians strongly or somewhat disagreed with the statement that nature's value is for today not for tomorrow. 


\section{ENVIRONMENTAL CONCERNS}

Environics has polled Canadians about their opinions related to environmental concerns in a variety of ways:

\section{- Ranking of Environmental Concerns}

Over the years, Canadians have been asked about their level of concern about various environmental issues and natural resource management issues. These issues included water quality, water pollution, the state of natural resources, the depletion of natural resources, climate change, the state of wildlife and their habitat, wildlife habitat destruction, species loss, the supply of trees, the amount of wilderness, use of biotechnology in agriculture and food production, the supply of prime agricultural land, the use of fossil fuels, the supply of oil and gas, and the production, transportation and use of oil. In 1992, the question was asked in a different manner, focusing on the "future supply of natural resources." Finally, Environics asked Canadians in 1990 whether they thought that the quality of the environment would be in a better or worse state in 10 years time. As a follow-up in 2002, Canadians were asked if they thought that environmental quality in Canada had improved or worsened.

- Water Quality, Agricultural Land, Loss of Species and Biodiversity, and Land Use Canadians have been polled more specifically about their opinions related to water and to agricultural land on a regular basis. Canadians were also asked more specific questions related to sustainable agriculture. Other questions have sought indications of public opinion about the loss of species and biodiversity and about land use including land use decisions, the value of land uses, and management of wilderness areas.

A number of general conclusions can be made based on a review of these Environics results.

- Canadians consistently are aware of and express concern about environmental and natural resource issues. One could conclude that they will continue to be concerned about management of natural resources and decisions about their use, especially in light of increasing demands and increasing conflicts between various resource sectors.

In 1990, 47\% of Canadians (Albertans 57\%) anticipated that the quality of the environment would be worse and only $31 \%$ (Albertans 25\%) thought that it would be better in ten years time. As a follow up in 2002, Canadians were asked if they thought that environmental quality in Canada had improved or worsened over the past ten years. The numbers were split, with $42 \%$ (Albertans $42 \%$ ) indicating they believe conditions have improved somewhat or greatly, and a slight majority at $53 \%$ (Albertans 53\%) believing that it has worsened somewhat or greatly. 
- Water is a valued natural resource for Canadians. They have consistently expressed concerns about water quality when asked about their environmental concerns. When asked specifically about water, drinking water quality and the quality of coastal waters, lakes and rivers are the greatest areas of concern, as would be expected.

It is interesting to note that, although it is much smaller, there has been a consistent level of concern about potential water shortages. In 2002, there was a significant increase in both the provinces of Saskatchewan and Alberta in the percentage of those responding that they were most concerned about potential water shortages. In Alberta, the percentage increased 16 points from 6 to $22 \%$. Environics concluded that "this rise in concern is probably due to prolonged drought in these regions of late."

- When looking at the agricultural sector, there appear to be two different aspects of concern to Canadians. The greatest area of concern is the use of agricultural chemicals - an issue of importance due to its relation to human health. Concern about the use of farm chemicals increased steadily over the period of 1989 to 2002.

In 1989, 31\% of Canadians and 26\% of Albertans identified the use of farm chemicals as their greatest land use concern. In 2002, the percentages had increased to $45 \%$ of Canadians and $45 \%$ of Albertans.

Environics

- Canadians are also concerned about topics related to management of agricultural land and land use decisions. Loss of farmland had the second highest percentages of Canadians identifying it as the greatest agricultural land use concern. Loss of soil through erosion and declining soil quality were identified by significantly lower proportions of Canadians but were identified on a consistent basis. The proportions identifying these topics as their greatest concern were generally higher in Alberta.

In Alberta, there was a dip in concern about loss of farmland in the mid 1990 's, with a return to earlier levels by 2002. In the year 2002, 26\% of Albertans identified loss of farmland as their greatest agricultural land use concern.

Environics 
- When Canadians were asked specifically about the issue of species loss and biodiversity, they indicated that it is a major concern.

In the year 2000, a full $82 \%$ of Canadians (70\% of Albertans) replied that the problem of species loss is becoming very serious.

Environics

- Canadians consistently placed conservation priorities ahead of economic priorities when asked which should most influence land use decisions. It appears that there may be a shift to a belief that both should be considered equally. This could reflect an increased understanding of and expectations for sustainable development.

In 1990, 10\% of Canadians, 9\% of Albertans, replied that both conservation and economic priorities should have equal influence in land use decisions. In 1991, these numbers rose to $12 \%$ of Canadians, $17 \%$ of Albertans; in 1993, 17\% of Canadians, $18 \%$ of Albertans. This reflects a continuing rise in the numbers of Canadians who think both priorities should be considered equally.

Environics

- Canadians appear to be more concerned about land use decisions affecting "remote wilderness areas" than those affecting "built-up areas or areas close to built up areas". It can be anticipated that there will be public concern as conflicts between the various resource sectors and land uses put increasing pressures on the landscape.

In 1993, Canadians were asked if they were most concerned with the impact of land use decisions when they affect built-up or urban areas, areas close to built-up areas, or remote wilderness areas. The highest percentage of Canadians, $47 \%$ (Albertans 59\%) replied that they are most concerned with decisions affecting remote wilderness areas.

Noticeably smaller proportions replied that they are most concerned with decisions affecting areas close to built-up areas (Canadians 22\%, Albertans 13\%) or built-up/ urban areas (Canadians 21\%, Albertans $21 \%)$.

Environics

- Success in achieving sustainability could be expected to change the public's perceptions and levels of concern about the natural resource sectors.

In 1993, Environics concluded the following. "Clearly, there is antagonism to the idea of land being used for housing or forestry, probably because both of these uses are seen as "using up" or destroying the productive qualities of land. On the other hand, the 
concepts of land as the basis of our agriculture industry and home to wildlife - both uses that rely on the ability of land to renew itself-are firmly ensconced in the Canadian consciousness." 


\section{PUBLIC POLLING - OTHER OPINIONS}

Polling other than Environics polling has confirmed that environment is a priority issue for Albertans generally. In the October 2004 It's Your Future survey conducted by the Alberta government, $58 \%$ of respondents gave "protect Alberta's environment" a high priority. This ranked third behind "provide a quality, affordable Alberta health care system" and "provide an outstanding education system".

Recently, Globescan polled Albertans (2003) and found that:

- The most serious environmental problems facing Alberta 10 years from now are water and air pollution.

- The greatest water problem relates to drinking water quality.

- The highest priority for protecting nature is pollution.

- The result if no action is taken to reduce species loss over the next 20 years is species loss will seriously affect the planet's ability to sustain life.

A City of Calgary survey in April 2004 confirms the importance of the environment to a large proportion of southern Alberta's population. Results indicated that environment is a top-of-mind concern for half of Calgarians, a majority of Calgarians believe the state of Calgary's environment is good today, half of Calgarians believe that the state of environment will be worse in the future, and $82 \%$ of respondents agree that the City should consider the environment in all decisions it makes. 


\section{FUTURE SUMMIT 2002}

http://www.futuresummit.com/

\section{PROCESS}

\begin{tabular}{|l|l}
\hline Province-wide consultation with Albertans & September to December 2001
\end{tabular}

- including workbook (online and hard copy), 11 Regional Forums and more than 60 MLA meetings for constituents

Future Summit meeting - delegate's package prepared using input from the consultation in 2001

Future Summit Alberta 2002, Imagine our tomorrow...A Report to the Government of Alberta delivered to government

Future Summit Alberta 2002, Imagine our tomorrow... Final Report and Imagine our tomorrow... Highlights released to the public

\section{RESULTS}

Future Summit Alberta 2002, Imagine our tomorrow...A Report to the Government of Alberta including:

- an overall vision for the future, with values and guiding principles

- sections on 7 themes:

The Economy

The Environment

Fiscal Responsibility

Communities

Health and Wellness

Learning

Governance

- for each theme, there is a Vision statement, Guiding Principles and Strategies and Ideas for Action

\section{KEY POINTS - THE ECONOMY}

What Albertans Had to Say (summary of public comments from workbook, regional forums, MLA meetings for constituents -4000 participants)

Albertans identified four major economic drivers:

- diversification of the economy 
- strategy - While Albertans mentioned specific sectors, their responses tended to refer to goals or to elements that needed to be in place in order to achieve certain goals. Key strategies included education, research and development, and health...

- traditional industries

- quality of life - Albertans mentioned a balanced lifestyle, the environment, recreation and culture (including the arts, entertainment and libraries).

\section{Recommendations}

Future Summit delegates proposed the following strategies for achieving their vision for the economy:

- Create a comprehensive, long-term, economic plan that extends over a number of business and political cycles and addresses infrastructure, fiscal policy and environmental needs.

- Continue to foster a globally competitive market economy.

- Pursue excellence in education at all levels - from preschool through postsecondary and beyond.

- Ensure that Alberta's economic development strategy recognizes the diversity within the province - capitalizing on the opportunities this presents and addressing the challenges.

- Create and sustain a culture of entrepreneurship and innovation.

\section{KEY POINTS - THE ENVIRONMENT}

What Albertans Had to Say (summary of public comments from workbook, regional forums, MLA meetings for constituents -4000 participants)

Albertans identified a wide range of concerns related to environmental protection. These included:

- preservation and expansion of parks and natural areas - many people saw green spaces, protected areas, special places, etc. as an integral part of Alberta preservation of these areas important for Alberta's future

- water quality, treatment, availability and supply - need to maintain drinking water quality, ensure proper water treatment and to protect watersheds

- forestry management practices - some concern about over-harvesting, reforestation, impact of cutlines on landscape

- sustainable agriculture - concern about the need to protect agricultural lands from industrial development and urban sprawl/ need for water conservation and environmentally responsible agricultural practices/ a number concerned about confined feeding operations and impacts of chemicals

- air and water quality, pollution and waste management - industrial emissions were of particular concern/ a few noted concerns about greenhouse gases

- impacts of population growth and economic development on parks, natural areas and agricultural land - some proposed that growth and development be controlled 
Albertans saw many challenges related to the environment. Many spoke about the need to find the right balance between the environment and the economy...Albertans saw environmental stewardship and sustainable development as key elements for preserving and protecting our environment. They believed that education, research, technology and innovation, regulation, incentives and planning will also play a role... Some noted the need for global as well as provincial or individual action.

- Environmental stewardship - Albertans advocated environmental stewardship

- Alternative energy and energy efficiency - finding alternatives to conventional energy sources was the most frequently recommended approach for protecting the environment/ many Albertans recommended energy conservation or efficiency measures/ reducing the impact of vehicles was an important issue/ a few Albertans recommended implementing the Kyoto Protocol while a few opposed the Protocol in its present form

- Environmental education - Albertans recognized that education is critical for ensuring a healthy environment/ if all Albertans understand their options and the consequences of their actions, they will make responsible decisions that help sustain the environment/ environmental education should be formal as well as informal/ Albertans believed that education is the key to environmental awareness

- Research and technology - many Albertans commented on the importance of technology in creating economic opportunities that are good for the environment/ some saw research as supporting the development of new technologies, particularly those related to alternative energy and energy efficiency

- Recycling and waste management - Albertans expressed strong support for recycling programs/ a number raised other waste management issues, including the need to reduce packaging, reduce the need for landfills, stop littering and do more composting

- Regulation, incentives and planning

- regulation - many Albertans felt a regulatory approach was needed to ensure good environmental performance - particularly by industry/ they proposed strong environmental legislation, standards and monitoring, along with strong or stronger enforcement and penalties/a few opposed the privatization of parks and the concept of industry self-regulation with regard to environmental issues

- incentives - some Albertans proposed using incentives and taxes to reward and encourage good environmental behaviour and punish bad performers

- planning-many Albertans wanted to see our province's parks and natural areas maintained and/or expanded/ some wanted to see development in these areas limited or altogether prohibited/ some proposed ecotourism as an economic activity that would fit with limited development in parks or natural areas

- Albertans proposed a number of other strategies for reducing negative environmental impacts and addressing resource development issues including appropriate, efficient integrated resource management, land use and regional planning/ Albertans felt that planning would help manage or limit growth and development, protect specific areas and curb urban sprawl 
- partners in environmental protection - Albertans believed that individuals, governments, communities and businesses share responsibility for the health of the environment/ many Albertans believed that governments have a significant responsibility/Albertans saw the government's role as one of environmental regulation and leadership/ many Albertans felt that industry has an important role in environmental protection

\section{Recommendations}

Future Summit delegates proposed the following strategies for achieving their vision for the environment:

- Develop a long-term environmental protection plan that is well researched, proactive and founded on solid science. The plan must include sustainable strategies, enforceable standards and measurable results. Governments, businesses, communities and individual citizens should be partners in the development and implementation of this plan.

- Establish ongoing, reliable funding for environmental research and conservation initiatives.

- Implement a program of incentives to reward and encourage good environmental behaviour and punish bad performers.

- Implement multi-level environmental education programs to foster awareness and encourage action that will ensure the ecological integrity and sustainability of Alberta's environment.

- Promote innovative resource management practices and ensure that the use of our natural resources will not result in environmental damage.

- Set standards, evaluate performance and establish monitoring procedures to protect the environment and improve environmental conditions across the province.

- Promote regional planning initiatives that safeguard Alberta's land and water resources, protect ecologically sensitive areas and preserve green space while fostering environmentally friendly economic development. 


\section{AG SUMMIT 2000 AND AGRIVANTAGE}

http://www1.agric.gov.ab.ca/\$department/deptdocs.nsf/all/webdoc6541?opendocument

\section{PROCESS}

\begin{tabular}{|l|l|}
\hline $\begin{array}{l}\text { Ag Summit Workshop } \\
\text { - preceded by a 2-day leaders workshop, 12 constituency } \\
\text { meetings organized by MLA's, 12 regional town hall } \\
\text { meetings, 10 topic/sector specific meetings } \\
\text { - followed by an interactive website }\end{array}$ & June 2000 \\
\hline $\begin{array}{l}\text { Catalyst for Growth, Framework for Change-summary } \\
\text { of discussions }\end{array}$ & December 2000 \\
\hline $\begin{array}{l}\text { 13 Action Teams formed including } \\
\text { Land Use Core Action Team (LUCAT) } \\
\text { Environmental Stewardship Action Team (ESAT) }\end{array}$ & June 2000 \\
\hline $\begin{array}{l}\text { ESAT targeted consultation process } \\
\text { Discussion paper by LUCAT Towards the Development of } \\
\text { a Provincial Land Use Strategy for Alberta }\end{array}$ & $\begin{array}{l}\text { December } 2001 \text { to February } \\
2002\end{array}$ \\
\hline $\begin{array}{l}\text { LUCAT Conference - "The Land Supports Us All” - } \\
\text { attended by more than 700 people }\end{array}$ & January 2002 \\
\hline $\begin{array}{l}\text { Final report of ESAT Environmental Stewardship Action } \\
\text { Team, Action Plan }\end{array}$ & March 2002 \\
\hline $\begin{array}{l}\text { Final report of LUCAT Towards the Development of a } \\
\text { Provincial Land Use Strategy for Alberta, An Agricultural } \\
\text { Perspective }\end{array}$ & April 2002 \\
\hline $\begin{array}{l}\text { Collection of all 13 of the Action Team reports submitted } \\
\text { to the federal government, the provincial government and } \\
\text { the agricultural industry }\end{array}$ & Spring 2002 \\
\hline $\begin{array}{l}\text { Agrivantage - Final report to government and process } \\
\text { complete }\end{array}$ & December 2002 \\
\hline
\end{tabular}

\section{RESULTS}

Final Agrivantage Report, Building Tomorrow Together and the collection of 13 Action

Team reports. Each report includes recommendations.

\section{KEY POINTS - AGRIVANTAGE REPORT - BUILDING TOMORROW TOGETHER}

\section{Issues and Recommendations}

The Agrivantage final report includes a summary of issues facing the agri-food industry, and a series of 10 recommendations, including the following: 
Recommendation 1

The agri-food industry and government should support the Agricultural Policy

Framework and adopt a general strategy of voluntary compliance with its key elements.

(The five key elements of the Agricultural Policy Framework are: Food Safety and Food Quality, Environment, Science and Innovation, Renewal, and Business Risk

Management.)

\section{Recommendation 8}

The agri-food industry, government, and all Albertans should recognize the need for and commit to long-term investments that sustain a shared vision for the rural environment, economy, culture and quality of life.

\section{KEY POINTS - LAND USE CORE ACTION TEAM REPORT}

\section{Issues}

Land use issues in Alberta can be summarized as follows:

- Alberta can anticipate continued strong economic growth resulting in continued consumption of, and competition for, land by all sectors of the economy.

- Land use is currently not a provincial government priority. Land use policies are weak with no means of monitoring or enforcement.

- There is a lack of an overall provincial (government, industry and public) land use vision.

- The long term sustainability of Alberta's land base is at risk as higher quality soils continue to be taken out of production.

- Agriculturally productive soils must be recognized and respected as a finite non-renewable resource when it comes to changing land use - this precious commodity cannot be replaced once it is gone.

- Decision-making is fundamentally an issue of scale. Local issues are best dealt with locally and broader reaching issues should be dealt with regionally or provincially.

- Municipalities, together with the provincial government, play an integral role in the preservation of farmland and can play a greater role in mediating conflict and educating the public on land use matters.

- Current government and industry approaches to assessing the nature of agricultural operations, the importance of agricultural land and the development of appropriate policies to support agriculture are inadequate.

- Existing constraints of data sharing among industry and government need to be alleviated to facilitate effective and efficient decision making.

- Need improved communication and awareness of issues at rural/urban interface, and need improved communication process(es) to ratepayers and public.

- Resources are required to develop and distribute land use information, assess and promote new tools, inform the public and improve decision making regarding effective land use planning.

- Land use conflicts are rapidly escalating among users and sectors competing for the same finite resource. 


\section{Recommendations}

1. It is recommended that the province and municipalities, both urban and rural, form partnerships with all industry sectors and the public, regarding the development of a long term sustainable land use policy and regulation framework.

2. It is recommended that the Province of Alberta adopt a more rigorous approach to protecting agricultural lands by developing a province-wide framework of land use policies that are enforceable and based on input from Albertans.

3. It is recommended that local governments; their decisions makers and planners, both urban and rural, be provided with the technical support, resources and tools such as AIMFAR (Alberta's Information Management Framework for Agricultural Regions) to protect agricultural working lands.

4. It is recommended that the provincial government designate sufficient human resources and funding to investigate fiscal incentives and conservation programs to retain sustainable agricultural landscapes for future use and the benefit of Alberta's citizens.

5. It is recommended, that interested members of LUCAT continue, in the interim to promote LUCAT results and initiatives through communication, strategic planning and developing linkages with industry and government.

Note: key strategies/ actions are included for each recommendation in the full report

\section{KEY POINTS - ENVIRONMENTAL STEWARDSHIP ACTION PLAN}

- Economics and environmental stewardship are two sides of a single challenge, making a living from the land in the short term and doing so in a manner which will safeguard environmental well-being and productivity in the longer term, for future generations.

- ESAT believes that managers of agricultural landscapes should be recognized and valued not only for producing food and/or fibre, but for the accompanying environmental goods and services that good stewardship provides to society.

- Long-term sustainability can only be achieved if short-term viability is attained.

- The main objective of the Team was to sustain (enhance where degradation exists) soil, air, and water quality/ quantity through effective and responsible stewardship of the agricultural industry.

- An important outcome of this entire process (Ag Summit) was the realization of the interconnectivity of all sectors in the agricultural industry as well as to the environment from which the base resources are derived/ value supply chains operate very closely to ecological food webs/chains of a functioning ecosystem. 
The Action Plan includes the following problem statements:

1. Current agricultural practices/ policies do not always have a positive impact on the environment.

2. Public confidence in the environmental sustainability of agriculture is at risk.

3. Under the current economic situation, producers are finding it difficult to address environmental issues financially, in the short-term.

4. Current farm support payments are costly, will not solve producer's problems over the long-term, and are becoming increasingly unacceptable to society.

5. Globally, there is a trend to address environmental issues with economic incentives rather that through legislation/ regulation (command and control).

6. There is increasing evidence that market-based solutions to environmental issues are effective and will result in behavioural changes in the long-term.

7. Society requires environmental goods and services (food, clean air, water, soil, etc.)

8. Producers and rural land managers can produce these goods and services.

9. The additional costs associated with the production of these goods and services, must be jointly shared by all members of society.

\section{Goals}

1. Land managers understand the present and potential benefits and financial opportunities from producing environmental goods and services.

2. Society accepts that managers of agricultural landscapes and viable rural communities help to achieve everyone's environmental goals.

3. Environmental Goods and Services provided by managers of agricultural landscapes have value through market-based solutions, incentives and other economic instruments.

4. Policy barriers that limit the development of environmental goods and services are identified and removed.

Note: strategies and actions for each goal are included in the report. 


\section{ALBERTANS AND CLIMATE CHANGE}

http://www3.gov.ab.ca/env/climate/plan.html

\section{PROCESS}

\begin{tabular}{|c|c|}
\hline $\begin{array}{l}\text { Albertans and Climate Change: A Strategy } \\
\text { for Managing Environmental and } \\
\text { Economic Risks released }\end{array}$ & February 2002 \\
\hline $\begin{array}{l}\text { Albertans and Climate Change: A Plan for } \\
\text { Action: Draft for Discussion released }\end{array}$ & May 2002 \\
\hline Web-based survey targeted to Albertans & $\begin{array}{l}\text { Survey was posted on the web site from } \\
\text { September } 13 \text { to October } 4,2002 \text {, and a } \\
\text { total of } 268 \text { surveys were returned in the } \\
\text { study time frame }\end{array}$ \\
\hline $\begin{array}{l}\text { Public Consultation Survey Summary } \\
\text { Report } \\
\text { Banister Research and Consulting }\end{array}$ & \\
\hline $\begin{array}{l}\text { Stakeholder consultation sessions targeting } \\
\text { sector groups }\end{array}$ & $\begin{array}{l}12 \text { sessions were held from September } 3 \text { to } \\
\text { September } 25,2002\end{array}$ \\
\hline $\begin{array}{l}\text { Stakeholders Consultation Final Report } \\
\text { Ipsos Reid }\end{array}$ & \\
\hline $\begin{array}{l}\text { Albertans and Climate Change: Taking } \\
\text { Action - Alberta's action plan on climate } \\
\text { change released }\end{array}$ & October 2002 \\
\hline
\end{tabular}

\section{RESULTS}

Taking Action outlines Alberta's goals, targets and actions to reduce greenhouse gas emissions in the province.

\section{KEY POINTS - PUBLIC CONSULTATION SURVEY SUMMARY REPORT}

(Summary of public input from the web-based survey)

\section{Recommendations}

Core Principles - Should there be any additions to these principles?

- Stewardship - more responsibility for the environment must be taken by all parties

- Research - more research is required on the sources and types of emissions and their effects on the environment; greater investment should be made in research and development overall regarding environmental impacts

- Incentives, market mechanisms - more support (tax breaks, allowances, incentives) should be provided to stakeholders that make an effort to reduce emissions and preserve the environment; penalize stakeholders that negatively contribute to emission levels

- Education - there is a need for more public awareness campaigns 
- Impacts - there is a need to seriously consider the social and economic impacts any plan will have on Alberta; must consult with professionals and other governments locally, provincially, federally and globally to get their input on environmental issues.

Emissions Reductions - comments included:

- Research - invest more in research and development for alternative energy sources and clean technologies

- Incentives, market mechanisms - as above

- Education - provide more information to the public regarding emission controls

- Sustainable communities - increase funding to cities to promote a longer, more sustainable planning process to combat urban sprawl

- Regulatory regime - set provincial standards requiring improvement in fuel economy and emissions from now until 2012

- Create an economy not as contingent on emission-producing industry

Government Leadership - comments included:

- Regulatory regime - need to implement more strict regulations regarding automobile emissions; develop a monitoring system for emissions control

- Research - invest in research and development of alternative fuel technologies

- Incentives - provide tax incentives for clean energy users

- Public awareness - develop a stronger public awareness media campaign

- Develop sector agreements

- Constrain development of industries that have the likelihood to negatively impact the environment

Technology and Innovation - comments included:

- Incentives - as above

- Research - conduct further research into carbon sinks and their impact; legislate companies to invest in environmentally friendly research and development activities

- Education - educate large companies in the long-term benefits of investing in research and development companies

Energy Conservation - comments included:

- Incentives - as above

- Education - stronger public advertising and awareness programs

- Individuals and businesses must cut back on consumption of all energy sources

Storing Carbon in Agricultural and Forestry Sinks - comments included:

- Need more research to determine if carbon sinks provide an adequate long term solution; more research should be done

- More research should be done to confirm the amounts of carbon that is tied up annually in agricultural crop production 
KEY POINTS - STAKEHOLDER CONSULTATIONS - FINAL REPORT

(Summary of public input from the stakeholder consultation sessions for targeted sectors)

\section{Recommendations}

\section{General}

- Important role consumers will have to play/ some stakeholders would like to see more priority given to renewable energy sources in Alberta's plan

\section{Sectoral Agreements}

- Vast majority say that sectoral agreements can be a very effective way of addressing climate change

- Near universal agreement on the importance of regulation - important to have a regulatory backstop

- Incentives seen as an important part of convincing companies to go beyond "business as usual"

\section{$\underline{\text { Role for Government }}$}

- Stakeholders see a variety of roles for government to play in helping to support investment and encouraging emission reduction

- All stakeholders extremely positive about the emphasis on technology

- Incentives for investment in technology

- Government can support emission reductions by directly investing in the renewable energy sector

- Setting an example

- Streamlining regulatory regime - reduce administrative burden around developing new technologies/ avoid cross-departmental administration that is not co-ordinated

\section{$\underline{\text { Role of the Public }}$}

- Incentives and penalties to encourage more energy efficient choices

- Government needs to communicate more with Albertans about what will be required of them under the Alberta plan

- Education is the key to a long-term and sustainable reduction in GHG emissions

- Suggestions for energy conservation - energy efficiency in construction and operation of residential and commercial buildings, mandatory minimum fuel efficiency requirements for vehicles, mandatory vehicle testing, etc. 


\section{WATER FOR LIFE: ALBERTA'S WATER STRATEGY}

http://www.waterforlife.gov.ab.ca/

\section{PROCESS}

\begin{tabular}{|l|l|}
\hline $\begin{array}{l}\text { "Ideas Group" - discussion group of } \\
\text { Albertans asked to identify range of ideas } \\
\text { needed to establish a broad basis for public } \\
\text { discussion on water }\end{array}$ & December 2001 \\
\hline $\begin{array}{l}\text { Public consultation process - workbooks } \\
\text { (on-line or hard copy), 15 community } \\
\text { workshops, a random telephone survey } \\
\text { (1000 Albertans) and a web site }\end{array}$ & March 1 to April 15, 2002 \\
\hline $\begin{array}{l}\text { Water for Life - Pooling Your Ideas - } \\
\text { Summary of Consultation Results released }\end{array}$ & May 2002 \\
\hline $\begin{array}{l}\text { Minister's Forum on Water involving over } \\
100 \text { invited participants }\end{array}$ & June 6-7, 2002 \\
\hline $\begin{array}{l}\text { Water for Life - Minister's Forum on } \\
\text { Water - Summary Report of Advice } \\
\text { Received released }\end{array}$ & August 2002 \\
\hline $\begin{array}{l}\text { Draft strategy released for public review } \\
\text { and comment }\end{array}$ & March 2003 \\
\hline Final strategy released to the public & November 2003 \\
\hline
\end{tabular}

\section{RESULTS}

Water for Life: Alberta's Strategy for Sustainability includes:

- goals

- desired outcomes for the short, medium and long term

- key directions and actions revolving around three core areas of focus:

- Knowledge and Research

- Partnerships

- Water conservation

\section{KEY POINTS - WATER FOR LIFE - POOLING YOUR IDEAS - SUMMARY OF CONSULTATION RESULTS}

(Summary of public input from workbooks, community workshops, and telephone survey)

- The public consultation process was intended to gather information about (a) public perceptions of the current situation, (b) expectations for the future, and (c) preferences regarding choices that may become necessary in the future

\section{Issues}

- The areas Albertans feel are most important are pollution, supply of safe drinking water, improved knowledge about water conservation and protection of the aquatic environment 
- Most respondents believe that water will become increasingly scarce in the province and that water allocation will therefore become an important issue

\section{Top 5 Challenges}

- Participants were asked to consider a list of 10 suggested future challenges - the following were identified as the top 5:

- surface water and groundwater will be vulnerable to pollution and contamination

- access to safe drinking water will become a significant issue for Albertans

- citizens will need to know more about water systems and wise water use

- industrial and agricultural growth will increase demand for water in places where water is not always plentiful

- water will become an increasingly scarce resource in Alberta

\section{Other 5 Challenges}

- Respondents were moderately concerned Albertans may have to choose between the aquatic ecosystem and economic growth/many thought this was not an appropriate basis for policy, but some noted that it is a critical choice and we must determine what our priorities are.

- There were mixed responses to the challenge statements identifying the need for investment in infrastructure and infrastructure maintenance, and the possibility that water availability will limit growth in Alberta.

- Flood threat was rated lowest.

\section{Recommendations}

- $87 \%$ of workbook respondents agreed with the proposed objectives that would guide the water strategy

- healthy, sustainable ecosystems

- a safe, secure drinking water supply

- reliable, quality water supplies for a sustainable economy

- the knowledge necessary to make effective water management decisions

\section{Achieving Safe Secure Drinking Water}

- Participants agreed that the safety of drinking water is a concern in Alberta.

- A majority of telephone survey participants felt that the provincial government should share responsibility with small municipalities and private systems to ensure safe drinking water/ workbook respondents also felt the provincial government has a shared responsibility, however workbook respondents were more likely (than telephone survey respondents) to indicate that the owner or the municipality had the responsibility.

Reliable, Quality Water Supplies for a Sustainable Economy

- Participants were asked to respond to the following range of options

- determine groundwater availability throughout the province

- allow water license transfers

- set aside water for future population growth before there are any shortages 
- encourage more efficient use of water through pricing to reduce overall use

- investigate construction of storage reservoirs to capture water during high flow time, making it available during low flows for new operators

- allocate water based on its most beneficial, or valued, uses

- companies pay for and build their own water storage so they can "bank" water in high flow periods and use the water during low flow periods

- allocate all available water by "first in time/first in right" rule, then prohibit any further allocation of water in the basin

- investigate construction of closed diversions from another river basin

- investigate construction of open diversions from one river basin to another

- allocate water to further uses even if this potentially harms aquatic environments

- Wide-ranging opinions were received about these ideas with the overall response from both participants at community workshops and workbook respondents indicating a belief that the provincial government will have to consider changes to avoid future water supply and demand problems.

- Discussion of these options at workshops illustrated that choices about strategies for the future will not be straightforward.

\section{Water Conservation}

- Participants felt that improved water conservation is essential and strongly supported the options to educate Albertans about water conservation values and methods, to use best management practices for various sectors, and to have the government offer tax incentives for water conservation.

- Suggestions about using pricing as an incentive for water conservation received a mixed response - especially for pricing of household water.

\section{Safeguarding Alberta's Healthy Ecosystems}

- Both those who responded to the workbook and to the telephone survey strongly agree that it is necessary to safeguard aquatic environments in Alberta

- There was a high level of agreement with the following strategic options presented:

- develop water management plans that integrate protection of aquatic ecosystems with watershed and land use management

- identify sensitive aquatic environments or habitats that require additional protection

- determine how much water the aquatic environment requires to remain healthly

- determine the maximum amount of substances a river or lake can accept without causing harm

- determine the balance between the amount of water needed for the aquatic environment and the amount needed for economic growth within a water basin

- maintain an amount of water in aquatic environments that will protect ecosystems even though it may limit human use 


\section{Recommendations}

- The seven discussion groups at the forum raised similar key ideas about what a water strategy must address:

- a water management system that focuses on water basins - the provincial government must act as the leader and the accountable party in implementing a water management system focussed on each of the seven major water basins in the province

- a safe drinking water assurance program

- a long-term risk management approach

- assurance of water quality

- motivation of Albertans to use water wisely

- Forum participants asked the provincial government to increase its commitment to water management, including

- encourage the wise use of water

- increase efforts to assure safe drinking water

- protect water from contamination

- develop a long-term risk management approach to supply and demand

\section{Major recommendations from plenary sessions}

1. There should be significant emphasis on education and involvement of both stakeholders and the public in water management planning and implementation.

2. There should be significant emphasis on watershed planning and management.

3. The provincial government must specifically define the quality and quantity of water required in natural water systems to ensure environmental sustainability and must ensure this allocation is maintained.

4. The provincial government must ensure that Albertans are not exposed to unsafe drinking water.

5. Albertans must implement improved water conservation practices.

6. The provincial government should continue to prevent pollution and contamination of water, improved regulations, monitoring and enforcement are recommended.

7. A long-term forecast of supply along with improved demand and risk management approaches are needed to ensure good management in the future.

8. The provincial government must assure that "First in Time, First in Right" (FITFIR) allocations are secure, and yet must also improve allocation criteria and ensure flexibility to account for future needs and conditions.

9. The provincial government must be accountable for the safety and sustainability of water in Alberta, increased staff and skills are essential to future success. 


\section{$\underline{\text { Cautions, concerns and dilemmas }}$}

- water allocation process

- cost allocation

- aquatic environment allocation

- sustainable growth

- use of potable water for oil field injection

- climate change

- long-term benefits versus short-term costs

- inter-jurisdictional relationships

- inter-basin transfers

\section{Summaries of Team Discussions on 7 Themes}

Team 1 - Water Conservation

- water conservation is an urgent priority

Strategic Decisions Needed

- What are the best ways to effectively increase knowledge of the needs and benefits of water conservation?

- What actions will best achieve water conservation practices by all users and sectors?

Team 2 - Water Quality

- provincial government is already doing much to manage water quality effectively, but a strategic approach will be needed in the future

Strategic Decisions Needed

- What are the best ways for the provincial government to ensure that Alberta's surface and groundwater is of the highest quality (safeguarded from contamination and pollution)?

- What are the best ways to improve existing conditions of water quality?

- What can we do to encourage innovation in improving, maintaining and sustaining water quality?

Team 3 - Drinking Water

- there is a need for significant changes to ensure Albertans are not exposed to unsafe drinking water

Strategic Decision Needed

- What are the best ways for the provincial government and its municipal partners to inform Albertans and ensure that they are not exposed to unsafe drinking water?

Team 4 - Aquatic Ecosystems

- propose an increased priority on protection of aquatic ecosystems, noting the following strategic direction 
- highest priority was placed on stakeholder involvement in planning, and on public communication of watershed trends - team also supported increased research, communication and guidelines to ensure the aquatic ecosystem is protected

Strategic Decisions Needed

- Take a watershed management approach to maintain ecosystem functions.

- Improve public awareness and understanding of watersheds, their components and their functioning.

- Make management and protection of aquatic ecosystems as important as health, education, infrastructure in the priority budgeting system of the provincial government.

Team 5 - Water Supply

- strategic management in this area is needed

Strategic Decisions Required

- Develop an authoritative supply forecast and demand management approach over the arc of the 30-300 year time frame.

- Where scarcities/ excesses exist, assure security of supply within risk management standards.

- Implement closed diversion of domestic water within Alberta in some situations.

Team 6 - Water and its Role in the Economy

- the team noted that the expansion of river basin plans to include all major basins in the provincial government was essential to good governance, and also noted that public/private partnerships would play an expanded role

Strategic Decisions Required

- What performance measures and indicators are needed to guide use of water in support of improved productivity?

- What options will develop synergies between economic growth and social needs?

- How to coordinate use most effectively?

- What can be done to improve productivity of our water resource?

Team 7 - Governance

- governance is the glue that holds the four water strategy objectives together

Strategic Decisions Required

- What governance framework can be developed to ensure effective water management?

- What are the roles and responsibilities of the provincial government and stakeholders involved in this governing framework? 


\section{SOUTH SASKATCHEWAN RIVER BASIN WATER MANAGEMENT PLAN}

\section{http://www3.gov.ab.ca/env/water/regions/ssrb/index.asp}

\section{PROCESS}

\begin{tabular}{|l|l|}
\hline $\begin{array}{l}\text { Meetings of Basin Advisory Committees } \\
\text { for each of the four sub-basins within the } \\
\text { South Saskatchewan River Basin }\end{array}$ & October 2001 to January 2002 \\
\hline 7 public open houses & January 2002 \\
\hline $\begin{array}{l}\text { Phase 1 - Water Allocation Transfers } \\
\text { complete, Phase 1 plan released }\end{array}$ & June 2002 \\
\hline $\begin{array}{l}\text { Phase 2 - Water Management Policy and } \\
\text { Strategy for Protection of the Aquatic } \\
\text { Environment - Terms of Reference } \\
\text { completed }\end{array}$ & June 2003 \\
\hline $\begin{array}{l}\text { Meetings with the Basin Advisory } \\
\text { Committees and public open house }\end{array}$ & \\
\hline Meetings with Basin Advisory Committees & \\
\hline $\begin{array}{l}\text { Submission of Basin Advisory Committee } \\
\text { recommendations for Phase 2 to } \\
\text { government }\end{array}$ & July 2004 \\
\hline $\begin{array}{l}\text { Draft Phase } 2 \text { Plan released for public } \\
\text { review }\end{array}$ & Oct 2005 \\
\hline Deadline for public review and comment & December 9, 2005 \\
\hline $\begin{array}{l}\text { Submission of final Water Management } \\
\text { Plan for approval }\end{array}$ & \\
\hline
\end{tabular}

\section{RESULTS}

Alberta Environment is developing a water management plan to maximize the benefits of water use in the South Saskatchewan River Basin (SSRB) in a sustainable and environmentally responsible way. The completed Phase 1 plan establishes a system for water allocation transfer in the SSRB. Phase 2 will address water management issues including the availability of water for future allocations and river flows for the aquatic environment. Phase 2 seeks to find the best balance between water consumption and environmental protection in the SSRB. This includes defining water conservation objectives (i.e. the flow to remain in rivers) after consideration of economic and social values and ecological requirements.

\section{KEY POINTS}

\section{Issues}

- Issues addressed in this planning process have arisen as the result of questions about the availability of water in the SSRB. 
- Alberta Environment has investigated water availability in the SSRB by means of computer simulations. This investigation produced evidence that the demand for the water resource is rapidly reaching, or in some areas has exceeded, the water supply.

- The following questions about implementation of water allocation transfers were the focus of the preparation of the Phase one plan and the focus of public discussions:

- What matters or factors must be considered by the Director when making a decision on an application to transfer an allocation under licence?

- Should there be water conservation holdbacks?

- What information should Alberta Environment be tracking concerning water allocation transfers?

- Should Alberta Environment continue to issue licences for new water allocations in highly allocated basins, where new licences will not have an assured water supply?

- Many other issues that became evident after this planning initiative started were identified and considered.

- The following were identified as points for which there was broad public support across the SSRB:

- There were many concerns regarding timeliness and input opportunities in the planning process.

- There was general support for transfers with some reservations and concerns/ it was considered a good tool but not without some downsides that must be managed.

- Impacts of transfers need careful monitoring/ there was concern about longterm social and economic impacts of transfers.

- There was strong interest in water availability and water conservation objectives.

- There was much interest in the big picture and long-term water issues

- Strong support was expressed for holdbacks to protect the aquatic environment.

- More information to educate/ support newcomers to water planning who do not know the recent history of the new Water Act was requested.

- Full details of the public discussions from Phase 1 are compiled in 2 documents, South Saskatchewan River Basin Management Plan, Phase One, Results of Consultation with the Basin Advisory Committees and General Public, OctoberNovember, 2001, and Results of Consultation with the Basin Advisory Committees and General Public, Phase One, January - February, 2002

- A description of previous consultation outcomes was included in the terms of reference for Phase 2 of the planning process. Listed are the outcomes from the consultations that are relevant: 
- Provide more time and opportunity for public input into the planning process.

- There is strong interest in looking at water availability and water conservation objectives.

- There was significant public interest in looking at longer term water issues in the SSRB.

- More information should be provided to educate/support newcomers to water planning who do not know the recent history of the new Water Act. 


\section{RURAL DEVELOPMENT STRATEGY}

http://www.rural.gov.ab.ca/

\section{PROCESS}

\begin{tabular}{|l|l|}
$\begin{array}{l}\text { Workshop with selected stakeholders to } \\
\text { develop conceptual building blocks for } \\
\text { scenarios describing alternative futures for } \\
\text { rural development }\end{array}$ & \\
\hline $\begin{array}{l}16 \text { community focus group sessions across } \\
\text { the province with selected stakeholders, to } \\
\text { identify elements that are challenges to } \\
\text { rural development in Alberta }\end{array}$ & Summer 2002 \\
\hline $\begin{array}{l}\text { Discussion meetings to be hosted by the } \\
\text { two co-chair MLAs, to determine possible } \\
\text { recommendations or implementable ideas } \\
\text { based on the issues heard }\end{array}$ & Spring 2003 \\
\hline Questionnaire available to the public & deadline June 27/03 \\
\hline Report submitted to government & June 2003 \\
\hline Rural Development Strategy & Feb 2004 \\
\hline
\end{tabular}

\section{RESULTS}

The Rural Development Strategy is intended to provide a framework for initiatives, programs and policies that will help the province's rural communities grow.

A Place to Grow: Alberta's Rural Development Strategy includes:

- a vision statement

- objectives and actions to be taken to strengthen the four pillars for sustainable rural communities

\section{KEY POINTS}

\section{Issues and Recommendations}

A summary report of "what was heard" was prepared to assist in the development of the strategy. This report summarizes information from the Future Summit, the Ag Summit (Agrivantage) and from the initial stakeholder discussions led by the Rural Development Initiative. The following are excerpts from the sections providing information from the discussions led by the Rural Development Initiative.

\section{$\underline{\text { Environment }}$}

Sustainable Resource Development (Water and Others) - Support and foster sustainable resource development in rural Alberta.

- Champion environmentally sustainable planning and integrated multi-stakeholder decision making for water, land, mineral, energy and other renewable resources. 
- Follow the planning process with environmentally sustainable and effective management of sustainable resources.

Land Use - The stewardship of our rural landscape resources is respected for its unique productive and conservation value.

- Balanced and integrated use of the land base is fostered.

- Maintain accessible wilderness.

Resource Conservation (Water) - Encourage and foster through long term planning, the conservation of our water and other resources.

- Balance the need for conservation with the needs for economic growth through planning for sustainability.

- Examine water re-cycling methods to expand the possible uses of our water resources.

\section{Government}

Local Decision Making - Strengthen local decision-making processes.

Governance - Support accountable government with sustainable long-term shared community/regional vision.

$\underline{\text { Regionalization }}$

Regionalization - Encouraging of strong regional and community partnerships will create new tools and methods to solve the complex issues facing rural communities.

\section{Technology}

Technology and Innovation - Technology and Innovation as drivers of Rural Development.

\section{$\underline{\text { Communities }}$}

Collaboration and Cooperation - Encourage broad-based collaboration and cooperation for mutual benefit of rural partners and stakeholders.

- Urban and Rural Partnerships focusing on the mutual benefit created by the rural drivers of the economy.

- Federal/Provinical/Municipal governments and appropriate regional groups, focusing on supporting a vibrant and sustainable rural quality of life.

Adequate and Sustainable Infrastructure - Support a stable infrastructure to connect rural communities with distant health and education options, and markets; and stable local infrastructure to ensure public education, health and safety.

- Support initiatives to maintain and enhance where appropriate access to rural utility, transportation and communication infrastructure systems. 
- Maintain support for local rural infrastructure systems.

- Maintain commitment to meeting environmental regulations. 


\section{C5 DETAILED FOREST MANAGEMENT PLAN}

http://www3.gov.ab.ca/srd/regions/southwest/c5/

\section{PROCESS}

\begin{tabular}{|l|l|}
\hline $\begin{array}{l}\text { Terms of Reference for Detailed Forest } \\
\text { Management Plan completed }\end{array}$ & April 2002 \\
\hline $\begin{array}{l}\text { Public Consultation - Public Advisory } \\
\text { Committee, stakeholder meetings, public } \\
\text { open houses, public questionnaire, web-site } \\
\text { for comments }\end{array}$ & January 2002 to December 2003 \\
\hline Development of draft plan & underway \\
\hline Public review of draft plan & \\
\hline Revision of draft plan & \\
\hline $\begin{array}{l}\text { Submission of recommended changes to } \\
\text { legislation (as required) }\end{array}$ & \\
\hline Final approval & \\
\hline $\begin{array}{l}\text { Completion of Regional Operating Ground } \\
\text { Rules }\end{array}$ & \\
\hline $\begin{array}{l}\text { Plan implementation } \\
\text { (Development of a new plan, and the }\end{array}$ & \\
resulting Operating Ground Rules are \\
required by April 30, 2006.)
\end{tabular}

\section{RESULTS}

The goal of this plan is to define a desired future forest state for the C5 Management Unit that demonstrates sustainability of the forest ecosystems, diverse social and economic benefits, today and tomorrow, through operational forest management systems and adaptive management.

Note: C5 Forest Management Unit - occupies 3,522 square kilometres of the Rock Mountain Forest Reserve Lands north of Waterton National Park and south of Kananaskis Country

\section{KEY POINTS}

Public pressure, recent EUB hearings and other large scale planning reviews (e.g. NRCB report for Vacation Alberta) have indicated that new approaches and a comprehensive land management strategy that minimizes impacts and ensures sustainability must be developed and implemented. (from Introduction of Terms of Reference)

The following issues overview is found in the Terms of Reference. It was prepared by staff based on their experience in the C5 Forest Management Unit. 
1. Coordinated Landscape Planning - land use management strategies must consider how coordination can be achieved to reduce the impact and ensure that the integrity of both the landscape and the important renewable resources can be maintained as sustainable

2. Watershed Management - the management unit contains the entire Oldman watershed - issues such as peak flows, beneficial release and water quality are all important

3. Biodiversity and Wildlife Habitat - the planning area is know for its wide range of biodiversity, which is closely related to the complexity of the landscape/ connectivity of habitats both within the planning area and between it and other areas is critical for the management of large carnivores

4. Oil and gas exploration and development - there are extensive reserves of natural gas within the management unit/ new technology and high gas prices have renewed interest in developing these gas fields/ access, aesthetics, wildlife habitat impacts and the impacts on other stakeholders must all be considered

5. Mineral exploration (primarily coal) - the management unit overlies extensive coal deposits, for which most of the mineral rights are privately held/ generally considered over the past 25 years or more that the development of these reserves would be unlikely/ current energy demands and high prices for energy may make extraction or use of this resource more attractive/ development of this resource would have substantial impacts on other stakeholders and resources users/ may also be development of coal-bed methane

6. Timber - timber industry is a major stakeholder in the management unit/ its activity can affect many of the components on the landscape

7. Range-livestock industry depends heavily on the planning area for livestock range and forage/ there are impacts from the use of this resource, depending on the level and type of range management done

8. Recreation - recreation also puts extreme demands on the landscape/ the impact of these demands is most likely the one that is most poorly understood

9. Aesthetics - visual values are increasingly important and there is a desire to ensure aesthetic qualities are considered in developments of any kind

10. Forest protection and management of invasive nonnative species (noxious weed and aggressive agronomic invaders)

11. Forest certification - Sustainable Forest Management Certification is desirable 


\section{Crowsnest Forest Survey Results}

"A survey by Alberta Sustainable Resource Development conducted to gather opinions and recommendations regarding the development of a new C5 Forest Management Plan concluded Dec 31/02. The four questions in the survey gathered public opinion on a wide range of activities and management practices occurring in the Crowsnest Forest. 482 people took part in the survey."

The following summary is taken from the C5 website:

Question 1: Are you a frequent user of the Crowsnest Forest? The majority of respondents (84\%) claimed to be frequent users of the Crowsnest Forest

Question 2: What is your primary reason for accessing the Crowsnest Forest? Just over half the respondents accessed the Crowsnest Forest for motorized recreation, followed by hiking or exploration on foot

Question 3: Have you noticed any changes in the Crowsnest Forest in the past five years that you do not like? $66 \%$ of respondents answered yes. The most widely mentioned concern was motorized recreation or off-highway vehicle use.

Question 4: Are there any changes that you would like to see in the Crowsnest Forest in the next five years? Respondents who suggested that changes be made (75\%) outweighed those viewing that change is not necessary $(18 \%)$ 


\section{SPRAY LAKE SAWMILLS DETAILED FOREST MANAGEMENT PLAN}

http://www.spraylakesawmills.com/Default.aspx?tabid=116

\section{PROCESS}

\begin{tabular}{|l|l|}
\hline $\begin{array}{l}\text { Draft Terms of Reference for Detailed } \\
\text { Forest Management Plan completed }\end{array}$ & \\
\hline $\begin{array}{l}\text { Plan for the Public Involvement Process } \\
\text { approved and public consultation initiated }\end{array}$ & Fall 2002 to Fall 2003; ongoing \\
\hline Public involvement process & November 2004 \\
\hline $\begin{array}{l}\text { Draft plan submitted for government } \\
\text { review }\end{array}$ & March 2006 \\
\hline Public review of revised draft plan & Sept 2006 \\
\hline $\begin{array}{l}\text { Revised plan submitted for government } \\
\text { review }\end{array}$ & \\
\hline
\end{tabular}

\section{RESULTS}

Spray Lake Sawmills received a Forest Management Agreement (FMA) on September 5, 2001. The company is required to develop long range forest management plans under the provisions of the FMA.

Note: The Spray Lake Sawmills FMA is the southern most FMA in the province, covering approximately 2800 square kilometres in a narrow band from Sundre to the southern end of Kananaskis Country.

\section{KEY POINTS}

Spray Lake Sawmills (SLS) reviewed public input from their McLean Creek and Etherington Creek public involvement processes and prepared the following list of issues and values pulled from those processes. This list is found in the Terms of Reference for the DFMP. "It is recognized that this list may change as SLS proceeds through its public involvement process. The updated issues/values list, in conjunction with the IRP's will then form the basis for the development of the objectives and strategies in the DFMP"

1. Access management - development of new access and the management/use of existing access.

2. Adaptive management - Company's ability to change management strategies and practices in light of new research and monitoring results.

3. Aesthetic values - concern over the impact of harvesting activity in areas of high visual sensitivity.

4. Biodiversity/ecological integrity - concerns over the effects of long-term timber harvesting on biological diversity and ecosystems. 
5. Community timber program - commitment to and sequencing of the fixed volume allocations.

6. Environmental protection - concerns over the impacts of industrial activity on the environment and soil productivity.

7. Forest protection - potential for timber losses from fire, insects and diseases.

8. Historical resources - concern over the potential loss of historical resource sites.

9. Integration - potential for the integration of other values, non-commercial uses and other industrial activity with timber harvest planning and operations.

10. Land base and tenure - security and the potential for land base losses.

11. Motorized recreational values - the issue of impacts and access management.

12. Non-motorized recreational values - the issue of impacts and access management.

13. Public involvement - process of public participation in the management of crown resources.

14. Public safety - potential for interaction between the public and SLS operations.

15. Reforestation - concern over the regeneration success in harvested areas.

16. Research - investment in and application of research.

17. Sustainable timber supply - issues and obligations in establishing and sustaining our level of timber harvesting based on ecological, economic and social needs.

18. Unique areas - concern over the potential loss of unique sites.

19. Water quality and quantity - the effects of timber harvesting and road construction/reclamation on the water and fish habitat resources.

20. Wilderness values and protected baseline areas - concerns over the effects of long-term timber harvesting.

21. Wildlife habitat supply - concerns over the effects of long-term timber harvesting. 


\section{RECREATION CORRIDORS LEGISLATIVE REVIEW}

http://www.cd.gov.ab.ca/all_about_us/legislation/rec_corridors/

\section{PROCESS}

\begin{tabular}{|l|l|}
\hline Workbook (on line or hard copy) & June to July 2002 \\
\hline Stakeholder forums, 9 community meetings & June to July 2002 \\
\hline Provincial forum & October 15, 2002 \\
\hline $\begin{array}{l}\text { Submission of Report by the Recreation } \\
\text { Corridors Legislative Review Committee }\end{array}$ & September 26, 2003 \\
\hline
\end{tabular}

\section{RESULTS}

Government has undertaken a review of the use of recreational corridors. The intention is to develop legislation for consistency in the development, the operation and the maintenance of recreation corridors in Alberta.

\section{KEY POINTS}

- The workbook prepared for public consultation includes a summary of concerns of some rural landowners/lessees, agricultural organizations, environmental organizations, businesses and resource companies about recreation corridor development, as follows:

- trespassing

- liability and insurance

- interference with landowner/lessee activities

- access control

- privacy

- vandalism and litter

- noise

- operation and maintenance

- The workbook also includes a summary of concerns of recreation corridor owners, operators and users, as follows:

- liability and insurance

- corridor protection

- trail stewardship

- sustainability

- guaranteed access

- safety

- The workbook sought public input on guiding principles and general legislative recommendations, and it sought public comment on the major topic areas as follows:

- Liability - insurance costs, trespass, liability reduction and related legislation 
- Safety and Policing - fire control, crime and vandalism prevention, emergency access, trail monitoring

- Operation, Maintenance and Accountability - planning, design, operational considerations

- Privacy and Access - noise, proximity to buildings, visibility, access rights, parking and ancillary facilities

- Environmental Stewardship - soil, water, wildlife, vegetation

- Other Topics - other topics that you feel are important

\section{KEY POINTS - REPORT TO THE MINISTER OF COMMUNITY DEVELOPMENT - APPENDIX 4 - RESULTS FROM PUBLIC CONSULTATION}

The results of the public consultation were summarized in an appendix to the Report to the Minister.

\section{Examining the Need for Legislation}

- there was a range of opinions - some questioned the need for new legislation, some suggested amendments to existing legislation might address concerns, some supported stand-alone legislation; most of those who commented believe there is a need for consistent regulation for recreational corridors

\section{Reinforcing the Role of Municipal Governments as Decision Makers}

- some agricultural representatives held the view that local government authority would be removed as a result of any new legislation; participants who expressed this concern indicated that the decision making authority should be left with local governments

\section{Difference Between Private and Public Land}

- there was a recommendation that designation of recreational corridors, along with the subsequent planning, design, operation and maintenance, consider the differences between public and private land

\section{Role of the Province}

- many participants indicated that the provincial government should take a leadership role in the designation of recreation corridors, in cooperation and coordination with municipal authorities; ownership, financial participation, coordination and the development of consistent standards for planning, design, operation, maintenance and creating awareness were seen as important roles for the provincial government; there were also some participants who felt that the provincial government should not be involved in trail designation and development 


\section{Develop a Vision and Clarify Definitions of Corridors and Trails}

- participants identified the need for a "vision" to guide the implementation of a designated recreation corridor system in the province

\section{Liability}

- concern was consistently expressed by landowners and lessees who believe they would be liable for careless or inappropriate actions of recreational corridor users; legislation should ensure that liability for landowners/ lessees and owner/operators be minimized, if not eliminated

\section{$\underline{\text { Safety and Policing }}$}

- there was a belief among some that there must be some method of compliance and enforcement for successful implementation; some expressed concern that recreation corridors may potentially encourage higher rates of vandalism, theft and trepass

\section{Operation, Maintenance and Accountability}

- there was a frequent suggestion that province-wide design standards, corridor mapping and information be coordinated and managed by the provincial government

- the need for public consultation throughout the corridor or trail application and establishment process was endorsed by participants

\section{Privacy and Access}

- there was a concern expressed by agricultural representatives around the potential loss of privacy and fragmentation of agricultural operations as a result of the establishment of recreational corridors; some recreational users and operators were concerned with the potential for a few landowners to prevent establishment of a recreation corridor that could benefit Albertans

\section{Environmental Stewardship}

- all interests supported the need to work together to ensure good environmental stewardship practices when locating, designing, constructing and maintaining recreation corridors

- some forestry, oil and gas and trapping interests whose developments are on public land indicated their concern that recreation corridors would become another form of "protected area" and potentially create a requirement for compliance or a limitation on their activities as part of an industrial application 


\section{GHOST RIVER / WAIPAROUS ACCESS MANAGEMENT PLAN}

\section{http://www3.gov.ab.ca/srd/regions/southwest/ghost/}

\section{PROCESS}

\begin{tabular}{|l|l|}
\hline $\begin{array}{l}\text { Public Survey - over 1100 surveys } \\
\text { completed }\end{array}$ & Jan - Feb 2003 \\
\hline $\begin{array}{l}7 \text { moderated discussion groups, with over } \\
60 \text { invited stakeholders attending }\end{array}$ & Feb 2003 \\
\hline $\begin{array}{l}\text { Random sample telephone survey -200 } \\
\text { rural residents and 200 Calgary residents }\end{array}$ & Feb 2003 \\
\hline $\begin{array}{l}\text { Draft new directions document released; } \\
\text { public invited to provide comments }\end{array}$ & Oct - Nov 2003 \\
\hline $\begin{array}{l}\text { Public information session on Draft } \\
\text { Operational Access Plan }\end{array}$ & April 2005 \\
\hline $\begin{array}{l}\text { Implementation of Operational Access } \\
\text { Plan; refinement of recreational trail } \\
\text { management system continuing }\end{array}$ & Spring/ summer 2005 \\
\hline $\begin{array}{l}\text { Completion of access management package } \\
\text { for submission to Minister of Sustainable } \\
\text { Resource Development }\end{array}$ & Oct 2005 \\
\hline
\end{tabular}

\section{RESULTS}

The Access Management Plan will contain a course of action and key directives for managing recreational OHV use and random camping in the Ghost-Waiparous area.

\section{KEY POINTS}

\section{Moderated Discussion Groups}

- The purpose of the moderated discussion groups was to identify key issues and concerns about the Ghost-Waiparous area and to generate possible solutions to the concerns.

- Some common areas of concern amongst the groups included:

- increasing conflicts between uses and users

- concerns about impacts on the environment identified in different ways including comments about sedimentation and erosion, the need for watershed protection, lack of ecosystem approach, sustainability of uses and the need for monitoring

- the need for public awareness and education

- public safety and health concerns

- enforcement issues/ control of uses in the area

- Each stakeholder group identified a comprehensive list of issues; summary reports of each of the sessions are available on the website. 


\section{Public Survey and Random Sample Telephone Survey}

- The public survey solicited the public's views and opinions about the existing challenges in the Ghost-Waiparous area and the most appropriate approach to managing human use in the area.

- The random sample telephone survey asked respondents about their use of the area and their opinions about how recreational use in the area should be managed.

- Eleven written submissions were also received.

- Summaries of the results are available on the website.

Directions Document and Survey (Oct-Nov 2003)

- A draft Directions Document was prepared for public review and was released in Oct 2003.

- The Directions Document and Survey included a summary of key issues, concerns and examples of recurring solutions that were consistently raised based on all of the information from the various public consultation initiatives; they were summarized under the following headings:

- public safety

- environmental protection

- management of random camping

- designated network of trails; formalized access staging points/ staging areas

- mitigating impact of large party groups

- A summary of the public comments on the draft Directions Document is available on the website. 


\section{BANFF NATIONAL PARK MANAGEMENT PLAN REVIEW}

\section{http://www.pc.gc.ca/pn-np/ab/banff/plan/index_e.asp}

\section{PROCESS}

\begin{tabular}{|l|l|}
\hline $\begin{array}{l}\text { Review and discussion of proposed } \\
\text { amendments to the Management Plan; } \\
\text { series of } 14 \text { meetings with key stakeholders } \\
\text { organizations; } 4 \text { public open houses }\end{array}$ & March to April 2003 \\
\hline Questionnaire (on line or hard copy) & deadline for responses April 30, 2003 \\
\hline $\begin{array}{l}\text { Responses compiled and summarized, and } \\
\text { made available to the public }\end{array}$ & \\
\hline $\begin{array}{l}\text { Draft amendments revised based on public } \\
\text { input }\end{array}$ & \\
\hline Management Plan amended & May 2004 \\
\hline
\end{tabular}

\section{RESULTS}

Management Plan updated on a 5 year basis.

\section{KEY POINTS}

- The Banff National Park Management Plan was approved in 1997; it is a 15 year document and legislation requires a review of the Management Plan every 5 years.

- Since the plan was approved in 1997, a Planning Forum has been held every year to provide an opportunity for stakeholders and the public to review progress and identify new issues requiring attention.

- Based on the discussions at the annual Planning Forums, several proposed amendments to the management plan were identified:

- a revised Grizzly Bear Strategy

- a Human Use Management Strategy

- a broadened suite of indicators

- 3 additional amendments were provided to the public for information:

- Frontcountry Visitor Accommodation Outside the Communities

- The Community of Lake Louise Community Plan

- Tertiary Sewage Treatment and Phosphate Removal (this amendment corrects an error in the original plan)

- A summary of the public comments was prepared and is available on the website.

- While the comments focused on the amendments being proposed, the following are some selected comments of interest related to long term sustainability:

- Framework for the Conservation of Grizzly Bears 
- Some respondents reiterated the importance of science and public consultation in decision-making; these people emphasized the need to ensure that management strategies are based on objective, peer-reviewed science, as well as discussions with stakeholders and the public

- The Draft Human Use Management Strategy

- Most respondents supported some form of human use management in Banff National Park. The comments reflect diverse points of view about the extent to which use should be managed in order to ensure maintenance of ecological integrity.

- A Regional Approach for Managing Human Use

- There was support for a regional management approach to address human use and ecosystem functioning across federal, provincial, and municipal jurisdictions.

- Managing for Human Use and Grizzly Bears

- Respondents were largely supportive of the need to manage human use in order to protect grizzly bears. However, there were divergent opinions about the priorities for management - wildlife, people, or a balance between the two.

- Ecological, Social, Cultural and Economic Indicators

- Respondents were generally supportive of the use of indicators to track ecological, social, cultural, and economic changes in the Park.

- Information on management planning and the annual Planning Forums is available on the website; a State of the Park report was prepared in 2003 and is also available on the website.

Note: As the management plans for Yoho, Kootenay and Waterton Parks address similar issues and affect many of the same stakeholders and park users, the plans for these parks were reviewed at the same time as the Banff National Park Management Plan. While the Banff National Park Plan was prepared in 1997, the plans for the other mountain parks were more recent having been approved in 2000 . Only minor updating of these plans was required. Most of the mountain park plans are now under the same 5 year review cycle. 


\section{COALBED METHANE / NATURAL GAS IN COAL CONSULTATIONS}

http://www.energy.gov.ab.ca/335.asp\#Community

PROCESS
\begin{tabular}{|l|l|}
\hline $\begin{array}{l}\text { Pre-consultation meeting with stakeholder } \\
\text { groups }\end{array}$ & Sept 2003 \\
\hline $\begin{array}{l}\text { Establishment of multi-stakeholder } \\
\text { advisory committee } \\
\text { establishment of working groups }\end{array}$ & November 2003 \\
\hline Community Information Sessions & Spring 2004 \\
\hline $\begin{array}{l}\text { Release of Preliminary Findings for public } \\
\text { review }\end{array}$ & July 2005 \\
\hline $\begin{array}{l}\text { On-line or hard copy comment form for } \\
\text { response by the public }\end{array}$ & Sept 30, 2005 \\
\hline $\begin{array}{l}\text { Final report from advisory committee to the } \\
\text { government }\end{array}$ & 2005 \\
\hline
\end{tabular}

\section{RESULTS}

The Alberta government is reviewing the regulations that govern natural gas in coal development to ensure that they continue to balance economic benefits for Albertans with protecting the land, air and water resources.

\section{KEY POINTS}

The following issues list was prepared and ratified by the Multi-Stakeholder Advisory Committee on Feb 9, 2004 to help establish the working groups.

This list was based on stakeholder input from the pre-consultation meeting, the community information sessions, the Sept 2003 Canadian Association of Petroleum Producers NGC position paper and the June 2003 Pembina Institute paper on Unconventional Gas.

\section{Potential NGC Issue Categories}

Water

- sustainability of aquifers

- potential for commingling of different quality water

- appropriate approach for the use and/or disposal of saline and non-saline water

- potential gas migration into aquifers

- possible contamination of aquifers

- clarify roles of the Energy and Utilities Board, the Department of Environment, and the Department of Agriculture, Food and Rural Development in relation to water 
- cumulative impacts of dewatering aquifers

- baseline information requirements for aquifer quality and quantity

- abandonment and reclamation on liability related to water

- hydraulic fracturing fluids

- radioactive tracers

Surface/ Air Impacts

- well density

- flaring and venting

- noise and dust of industrial activity

- infrastructure requirements

- competing land use interests

- environmental impact (habitat fragmentation)

- cumulative impacts

- balance between NGC development and local communities

- setback requirements

Regulatory Processes

- application approval processes (Sustainable Resource Development, Environment, Energy and Utilities Board)

- project based integrated development plans

- resources to monitor and enforce regulatory compliance

Information and Public Awareness

- public involvement in applications and approval process (Sustainable Resource Development, Environment, Energy and Utilities Board)

- use of best industry practices/guidelines

- inform Albertans about NGC development compared to conventional gas

- access to data (e.g. duration of data confidentiality, experimental status)

- data collection requirements for industry and public (Energy and Utilities Board)

- long-term value for Albertans (revenue, jobs, etc.)

- community development impacts

Innovative Technologies

- research to improve development and extraction methods

Royalty

- appropriateness of existing royalty regime for NGC

Mineral Land Tenure

- administration of petroleum and natural gas leases

- crown/freehold mineral ownership 


\section{INTRODUCTION}

Environics surveys Canadians on environmental issues on a regular basis over the year, with results published in the Environmental Monitor. A scan of the Environmental Monitor reports from 1989 to 2002 was undertaken to identify if there had been any significant changes in public opinion over a period of about one decade. The following is a summary of key points found through this scan. This is a subjective analysis of the information and is intended only to identify broad trends and issues relevant to the Southern Alberta Sustainability Strategy process. (Alberta Environment has subscribed to the Environmental Monitor since 1989.)

\section{SUSTAINABLE DEVELOPMENT}

\section{SUPPORT FOR SUSTAINABLE DEVELOPMENT}

Environics asked Canadians in 1989 if sustainable development - "a new term that means developing our economy in a way that minimizes damage of the environment, so that it is capable of supporting our economy and society over the long term" - should be a priority. Eight in ten (79\%) of Canadians ( $83 \%$ of Albertans) said that sustainable development should be a major priority for Canada. "These findings clearly confirm previous data showing that Canadians believe in the compatibility of environment and economic goals, but place pre-eminence on the former."

In 1990 and 1992, Canadians were asked if they had heard of the term sustainable development. In 1990, only $18 \%$ (Albertans $15 \%$ ) replied that they had; in 1992, only $23 \%$ (Albertans 21\%) replied that they had. However, in 1992, when sustainable development was described, $72 \%$ of Canadians (Albertans $72 \%$ ) said that it should be a priority.

In 1995, the question had changed somewhat. Canadians were asked what comes to mind when they hear the term sustainable development. Fifty percent of Canadians (Albertans $45 \%$ ) either had no opinion or said that nothing comes to mind. Among those who did give answers, the most common response was that it means renewable or long-lasting resources. Other responses included an immediate association with forests and forestry, protecting the environment, preventing damage and being environmentally friendly, not depleting resources, replacing what is used, balancing and benefiting the economy and the environment, recycling, conservation, farming and agriculture, mining, fisheries and concern about waste. 
By 1995, the number of Canadians responding that sustainable development should be a major priority for Canada over the next decade had increased to $81 \%$ (Albertans $75 \%$ ). "Clearly, as there is more and more discussion of the concept of sustainable development, particularly in such contexts as fisheries and forests, it is being seen as increasingly important."

\begin{tabular}{|l|c|c|}
\hline $\begin{array}{l}\text { Sustainable Development } \\
\text { Should be a Major } \\
\text { Priority for Canada }\end{array}$ & Canadians & Albertans \\
\hline 1989 & 79 & 83 \\
\hline 1992 & 72 & 72 \\
\hline 1995 & 81 & 75 \\
\hline
\end{tabular}

\section{THE ENVIRONMENT AND THE ECONOMY}

Environics has also asked questions about the relationship between the environment and the economy. Questions have sought indications of public opinion about the factors that should most influence economic development strategy, "tradeoffs" between environmental protection and economic development, the economic impact of environmental clean-up and protection, and impacts on levels of unemployment.

\section{What factor should most influence overall economic strategy for Canada?}

In 1990, environmental protection was identified most often, by $33 \%$ of Canadians (Albertans 33\%), as the consideration that should be the most influential factor in the creation of an overall economic strategy for Canada. A similar result was found in 1991, with $31 \%$ of Canadians (Albertans 30\%) identifying environmental protection as the most important factor. Later in 1991, with the recession at that time continuing, there was a shift with maximizing jobs identified most often, by $30 \%$ of Canadians $(24 \%$ of Albertans), as the most important factor to be considered. Twenty six percent of Canadians ( $24 \%$ of Albertans) continued to feel that environmental protection should be the most influential factor.

\begin{tabular}{|l|c|c|}
\hline $\begin{array}{l}\text { Consideration that should most influence } \\
\text { the creation of an overall economic } \\
\text { development strategy for Canada }\end{array}$ & $\begin{array}{l}\text { Environmental } \\
\text { Protection }\end{array}$ & $\begin{array}{l}\text { Maximizing } \\
\text { Jobs }\end{array}$ \\
\hline Winter 1990 & 33 & 22 \\
Canadians & 33 & 22 \\
Albertans & & \\
\hline Winter 1991 & 31 & 24 \\
Canadians & 30 & 23 \\
Albertans & & \\
\hline Summer 1991 & 26 & 30 \\
Canadians & 24 & 24 \\
\hline Albertans & \multicolumn{2}{|}{} \\
\hline
\end{tabular}


*Environics Question: If the government were to create an overall economic development strategy for Canada, which of the following considerations do you think should most influence the direction of this strategy? Environmental protection, maximizing jobs, regional development, research and development, foster Canadian companies.

\section{"Trade-offs" between the environment and the economy}

In 1994, Environics sought to get a sense of how Canadians perceived the tradeoffs between environmental and economic considerations. Canadians were asked "On a scale of 1 to 5, with 1 meaning protect the environment at all cost and 5 meaning to protect the economy at all cost, where do you feel the balance should be between the environment and the economy?" Forty-three percent of Canadians (Albertans 45\%) either answered 1 or 2 with the environment taking precedence. Another $41 \%$ (Albertans $41 \%$ ) answered 3 indicating that they want an equal emphasis on both economic and environmental considerations.

Another more direct question was raised in 1997, asking specifically about the tradeoff between environmental protection and economic growth. Almost three-quarters of Canadians (73\%, Albertans $78 \%$ ), "when presented with a choice, felt that protecting the environment should be given priority, even at the risk of slowing down economic growth." Six percent (Albertans 5\%) felt that both should be given equal priority.

In 2002, the question was again raised in terms of overall "tradeoffs" between the environment and the economy. Canadians were asked if they agreed with the statement "the economy does not need to suffer to ensure a healthy environment". Seventy six percent agreed strongly ( $40 \%$ ) or somewhat (36\%) (Alberta $73 \%$ total, $35 \%$ strongly agreed, $38 \%$ somewhat agreed). This suggested "that the belief that economic and environmental health are complementary is more widely held than the opposing view that an economic tradeoff is inherent in environmental protection."

In a subsequent question, seventy two percent strongly or somewhat agreed that "it is acceptable that an industrial society such as ours produces a certain degree of pollution." "Results of this question signify that Canadians are far from embracing a zero-tolerance attitude toward pollution...Other environmental Monitor research has shown, however, that Canadians expect environmental risks to be minimized and that they prefer that precautionary principles guide approaches to environmental management."

\section{The impact of environmental clean-up and protection on the economy}

In 1989, eight in ten Canadians (Canadians 79\%, Albertans 75\%) when asked, felt that the clean-up and protection of the environment would significantly contribute to economic growth (down from $83 \%$ in 1988). The numbers in 1990 and 1991 remained similar to 1989. In 1990, $83 \%$ of Canadians (Albertans $87 \%$ ) agreed strongly or somewhat. Canadians were asked the question twice in 1991. In the summer, $84 \%$ of Canadians (Alberta 87\%) agreed strongly or somewhat. In December 1991, the number 
was $81 \%$ of Canadians (Albertans $87 \%$ ). The number again remained consistent in 1992, going back up to $84 \%$ of Canadians.

In 1994, public opinion continued to be measured by asking about the potential benefit that environmental protection could afford to the economy. In 1994, a majority of Canadians (52\%, Albertans 50\%) thought that protecting the environment would involve somewhat more or much more opportunity for the Canadian economy than costs. Another $4 \%$ (Albertans 4\%) thought that there would be equal costs and opportunities.

In 1997, Canadians were again asked about the possible benefits of environmental clean up. More than eight in ten ( $86 \%$, Albertans $81 \%)$ strongly or somewhat agreed that the clean-up and protection of the environment will, in itself, contribute significantly to the growth of the economy. "As we have found in the past, Canadians do not feel that they will have to make serious economic tradeoffs in the interest of cleaning up the environment." In 2000 , more than eight in ten (83\%, Albertans $73 \%$ ) strongly or somewhat agreed that the clean-up and protection of the environment, would, in itself, contribute to the growth of our economy. "These findings have not varied significantly since Environics first asked this question in 1988".

\begin{tabular}{|l|c|c|}
\hline $\begin{array}{l}\text { Environmental clean-up will } \\
\text { contribute to economic growth }\end{array}$ & Canadians & Albertans \\
\hline $\mathbf{1 9 8 9}$ & 79 & 75 \\
\hline $\mathbf{1 9 9 0}$ & 83 & 87 \\
\hline $\mathbf{1 9 9 1}$ (summer) & 84 & 87 \\
\hline $\mathbf{1 9 9 1}$ (December) & 81 & 87 \\
\hline $\mathbf{1 9 9 2}$ & 84 & - \\
\hline $\mathbf{1 9 9 7}$ & 86 & 81 \\
\hline $\mathbf{2 0 0 0}$ & 83 & 73 \\
\hline
\end{tabular}

Responding to a different question in 1990, only $30 \%$ of Canadians (Albertans $26 \%$ ) believed that protecting the environment would increase unemployment. In 1991, only $26 \%$ (Albertans 21\%) strongly or somewhat agreed that protecting the environment would increase unemployment. The numbers continued in 1992, with only $29 \%$ agreeing that unemployment would increase.

\begin{tabular}{|l|c|c|}
\hline $\begin{array}{l}\text { Protecting the } \\
\text { environment will increase } \\
\text { unemployment }\end{array}$ & Canadians & Albertans \\
\hline $\mathbf{1 9 9 0}$ & 30 & 26 \\
\hline $\mathbf{1 9 9 1}$ & 26 & 21 \\
\hline $\mathbf{1 9 9 2}$ & 29 & - \\
\hline
\end{tabular}

In analyzing the responses regarding the impact of clean-up and protection of the environment and impacts on levels of unemployment, Environics concluded in 1991 that 
"Canadians do not feel they will have to make serious economic tradeoffs in the interest of cleaning up the environment."

In January 1996, the focus of the question was protection of the environment versus prices and jobs. Sixty two percent of Canadians (Albertans 65\%) strongly or somewhat disagreed with the statement that "We worry too much about the future of the environment and not enough about prices and jobs today." "There is clearly little sympathy with the argument that environmental regulation has gone too far and is costing too great an economic price." There had been a change by 1997. A majority of Canadians (56\%, Albertans $60 \%$ ) continued to strongly or somewhat disagree with the statement. However, the proportion who felt strongly had declined significantly from $33 \%$ to $23 \%$. (Albertans $36 \%$ to $29 \%$ ), and the number who disagreed somewhat with the statement had increased from $29 \%$ to $33 \%$ (Albertans $29 \%$ to 31\%). At that time it was stated that "Canada's continuing high levels of unemployment, despite improving economic growth, may be making Canadians sensitive to statements which also imply that not enough is being done about unemployment."

In 1998, Canadians were again asked about the impact of environmental protection on Canadian jobs. Only $24 \%$ of Canadians (Albertans $22 \%$ ) strongly or somewhat agreed that protecting the environment would increase unemployment. "These findings indicate that Canadians do not buy into the argument that environmental protection will lead to job loss. This is especially surprising considering the fact that other Environic's data affirm that unemployment is considered to be the most important problem facing Canadians today, and since 1993, this issue has topped all other issues of concern on the public agenda. Hence, although unemployment is a major concern among Canadians, they continue to feel, as other Environmental Monitor data has shown, that we will not have to make any serious economic trade-offs in the interest of cleaning-up the environment."

\begin{tabular}{|l|c|c|}
\hline $\begin{array}{l}\text { Protecting the environment will } \\
\text { increase unemployment }\end{array}$ & Canadians & Albertans \\
\hline $\mathbf{1 9 9 0}$ & 30 & 26 \\
\hline $\mathbf{1 9 9 1}$ & 26 & 21 \\
\hline 1992 & 29 & - \\
\hline 1998 & 24 & 22 \\
\hline
\end{tabular}




\section{CONCERN FOR FUTURE GENERATIONS}

Environics has asked a number of questions relating to future generations that can be linked to Canadians' views about long term sustainability.

\section{Priority of future generations over the present generation}

In 1994, Canadians were asked if they agreed with the statement "our first priority must be to meet the needs of the present generation of Canadians and let future generations look after themselves". Over eight in ten somewhat (Canadians 21\%, Albertans 19\%) or strongly (Canadians 63\%, Albertans 67\%) disagreed. "Canadians overwhelmingly reject the idea of placing our needs before those of future generations."

In 1996, the question was changed subtly, with Canadians asked whether we should base our decisions about major national problems mainly on the needs and desires of the present generation or mainly on the needs of future generations. "There is no question that Canadians are taking a very future-oriented approach towards decisions affecting society." A majority of Canadians (52\%, Albertans 49\%) replied that we should completely or mostly base decisions on the needs of future generations. "These results indicate that there is a mindset among a majority of Canadians that will be supportive of the concept of future sustainability over short-term economic gains."

Canadians were asked again in 1997 what we should base our decisions about major national problems on. Canadians continued to take a future-oriented approach with $49 \%$ (Albertans $44 \%$ ) replying that we should base decisions completely or mostly on the needs of future generations.

\section{Nature's value for today and for the future}

In the years 2000 and 2002, the question to Canadians focused on the natural environment, asking whether they agree or disagree that nature's greatest value is for today, not for future generations. In 2000,60\% of Canadians strongly disagreed and 14 $\%$ somewhat disagreed. In $2002,60 \%$ strongly disagreed and $16 \%$ somewhat disagreed (Alberta 70\%, 9\%). This indicates that nature is an important legacy issue for Canadians - they are concerned about what we are leaving for future generations.

\section{Greatest threat to future generations}

In another question asked in 1996, Canadians identified economic hardship (Canadians $40 \%$, Albertans 40\%), environmental problems (Canadians 19\%, Albertans 19\%) and the depletion of natural resources (Canadians 11\%, Albertans 10\%) as the greatest threats to future generations.

When asked again in 1997, Canadians continued to identify economic hardship (Canadians 33\%, Albertans 28\%), environmental pollution (Canadians 27\%, Albertans $33 \%$ ) and depletion of natural resources (Canadians 13\%, Albertans 13\%) as the greatest 
threats to future generations. There was a significant shift in the proportions, however, with the percentage identifying economic hardship dropping by seven points and the percentage identifying environmental pollution increasing by eight points. It is interesting to note that when Canadians were further asked what poses the second greatest threat to future generations, a plurality of Canadians $(26 \%$, Albertans $22 \%)$ replied environmental pollution. This resulted in a total of 53\% (Albertans 55\%) identifying environmental pollution as either the first or second greatest threat. In 1999, the replies were environmental pollution $29 \%$, economic hardship $20 \%$, and depletion of natural resources $18 \%$.

By 2001, the number of Canadians replying that environmental pollution is the greatest single threat to future generations had been growing steadily. The numbers were $35 \%$ (Albertans 35\%) identifying environmental pollution, 19\% (Albertans 19\%) economic hardship, and 13\% (Albertans 13\%) natural resource depletion. (Note: In 1996, the question referred to "environmental problems". This was changed to "environmental pollution" in subsequent years.)

\begin{tabular}{|l|c|c|c|}
\hline $\begin{array}{l}\text { Threats to Future } \\
\text { Generations }\end{array}$ & $\begin{array}{l}\text { Economic } \\
\text { Hardship }\end{array}$ & $\begin{array}{l}\text { Environmental } \\
\text { Problems/ } \\
\text { Pollution }\end{array}$ & $\begin{array}{l}\text { Natural Resource } \\
\text { Depletion }\end{array}$ \\
\hline $\mathbf{1 9 9 6}$ & 40 & 19 & 11 \\
Canadians & 19 & 10 \\
Albertans & 40 & 27 & 13 \\
\hline $\mathbf{1 9 9 7}$ & 33 & 33 & 13 \\
Canadians & 28 & 29 & 18 \\
Albertans & 20 & - & - \\
\hline $\mathbf{1 9 9 9}$ & - & 35 & 13 \\
Canadians & 19 & 35 & 13 \\
Albertans & 19 & & \\
\hline $\mathbf{2 0 0 1}$ & & & \\
Canadians & & & \\
Albertans & &
\end{tabular}

*Environics Question: In your opinion, which of the following is the greatest threat to future generations? Economic hardship, environmental problems, depletion of natural resources, wars and conflicts, diseases, lack of food, combination/ all, other, nothing/ no threats, dk/ na.

\section{Effects of environmental pollution on children and future generations}

In 1992 and 1993, Canadians were asked to rate their greatest concern regarding the possible negative effects of environmental pollution. The concern identified most often was the effect on children and future generations. This response was given by $38 \%$ of Canadians in 1992 (Albertans 41\%), and by 45\% of Canadians (Albertans 46\%) in 1993. "Clearly concern for the environment is very much connected to the issue of the kind of legacy we are leaving to future generations." The question was asked again in 1995. Thirty six percent of Canadians (Albertans 43\%) identified the effect on children and future generations as their greatest concern. This represented a significant drop of $9 \%$ for 
Canadians. Environics concluded that "These results indicate that, with regard to the environment, Canadians are becoming more focused on immediate health concerns and a bit less focused on the legacy we are leaving future generations." It is interesting to note, however, that the number for Albertans had only declined by $3 \%$.

\begin{tabular}{|l|c|c|}
\hline $\begin{array}{l}\text { Effect on children and } \\
\text { future generations as } \\
\text { greatest environmental } \\
\text { concern }\end{array}$ & Canadians & Albertans \\
\hline $\mathbf{1 9 9 2}$ & 38 & 41 \\
\hline $\mathbf{1 9 9 3}$ & 45 & 46 \\
\hline $\mathbf{1 9 9 5}$ & 36 & 43 \\
\hline
\end{tabular}

\begin{abstract}
*Environics Question: Environmental pollution could produce negative effects in a number of areas. Which one of the following concerns you the most? Your children and future generations, human health and safety, the survival of life on earth, Canada's wildlife, forests and natural areas, your leisure and recreational use of water and land.
\end{abstract}

A more focused question was asked in 1992, 1997 and 1999, with Canadians asked what impact they thought environmental problems would have on the health of our children and grandchildren. In 1992, 51\% thought that environmental problems will have a considerable effect on the health of our children and grandchildren. This number increased in 1997 to $58 \%$ and dropped back down to $50 \%$ in 1999 . In 1992, another $36 \%$ thought there would be a fair amount of impact. The number replying that there would be a fair amount of impact remained steady in 1997 at 35\% and increased in 1999 to $39 \%$. This reflects that there continued to be a significant concern about future generations. (The data for Alberta in 1997 are $52 \%$ a great deal of impact, 36\% a fair amount of impact. Data is missing for 1992 and 1999.)

In 2002, Canadians were again asked what impact they think environmental problems will have on the health of our children and grandchildren. Nine in ten Canadians $(88 \%$ Albertans $78 \%$ ) replied a great deal or a fair amount. Environics concluded that "Concern about the health of future generations may influence fundamental attitudes toward the environment. People who believe that the health of future generations will be affected a great deal by environmental problems are also inclined to agree that the environment does not need to suffer at the expense of economic growth, rejecting the notion that a tradeoff exists between the environment and the economy" (see Environics results and analysis on "economy and environment" above). 


\begin{tabular}{|l|c|c|}
\hline $\begin{array}{l}\text { Environmental problems will affect } \\
\text { the health of our children and } \\
\text { grandchildren }\end{array}$ & A Great Deal & A Fair Amount \\
\hline $\mathbf{1 9 9 2}$ & 51 & 36 \\
Canadians & - & - \\
Albertans & 58 & 35 \\
\hline $\mathbf{1 9 9 7}$ & 52 & 36 \\
Canadians & 50 & 39 \\
Albertans & - & - \\
\hline $\mathbf{1 9 9 9}$ & & \\
Canadians & 59 & 29 \\
Albertans & 46 & 32 \\
\hline $\mathbf{2 0 0 2}$ & & \\
Canadians & & \\
Albertans & & \\
\hline
\end{tabular}

An interesting question was posed in 1998. Canadians were asked how often over the past year they spent their recreation or leisure time in natural areas. Over eight in ten Canadians (84\%, Albertans $84 \%$ ) replied that they had very often (Canadians 50\%, Albertans 53\%) or sometimes (Canadians 34\%, Albertans 31\%) done so. One could expect that this would have an impact on Canadians' connections to natural areas and their perceptions and values. 


\section{ENVIRONMENTAL CONCERNS}

\section{RANKING OF ENVIRONMENTAL CONCERNS}

\section{Concern about environmental issues and natural resource issues}

Over the years, Canadians have been asked about their level of concern about various environmental issues. "Are you very concerned, somewhat concerned, or not very concerned about each of the following environmental issues..." The following summarizes the findings for selected environmental issues of interest.

\begin{tabular}{|c|c|c|c|c|c|c|}
\hline $\begin{array}{l}\text { "Very } \\
\text { Concerned" } \\
\text { only }\end{array}$ & $\begin{array}{l}\text { Water } \\
\text { Quality }\end{array}$ & $\begin{array}{l}\text { State of } \\
\text { Natural } \\
\text { Resources }\end{array}$ & $\begin{array}{l}\text { Climate } \\
\text { Change }\end{array}$ & $\begin{array}{l}\text { State of } \\
\text { Wildlife } \\
\text { and } \\
\text { their } \\
\text { Habitat }\end{array}$ & $\begin{array}{l}\text { Use of } \\
\text { Biotechnology } \\
\text { in Agriculture } \\
\text { and Food } \\
\text { Production }\end{array}$ & $\begin{array}{l}\text { Use of } \\
\text { Fossil } \\
\text { Fuels }\end{array}$ \\
\hline $\begin{array}{l}1989 \\
\text { Canadians } \\
\text { Albertans }\end{array}$ & $\begin{array}{l}74 \\
66 \\
\end{array}$ & $\begin{array}{l}54 \\
51 \\
\end{array}$ & $\begin{array}{l}44 \\
45 \\
\end{array}$ & & & \\
\hline $\begin{array}{l}1990 \\
\text { Canadians } \\
\text { Albertans }\end{array}$ & & $\begin{array}{l}49 \\
49\end{array}$ & $\begin{array}{l}46 \\
44\end{array}$ & $\begin{array}{l}54 \\
59\end{array}$ & & \\
\hline $\begin{array}{l}1992 \\
\text { Canadians } \\
\text { Albertans }\end{array}$ & & $\begin{array}{l}53 \\
55 \\
\end{array}$ & $\begin{array}{l}47 \\
49 \\
\end{array}$ & $\begin{array}{l}51 \\
58 \\
\end{array}$ & & \\
\hline $\begin{array}{l}1993 \\
\text { Canadians } \\
\text { Albertans }\end{array}$ & $\begin{array}{l}68 \\
68 \\
\end{array}$ & $\begin{array}{l}54 \\
58\end{array}$ & $\begin{array}{l}41 \\
38\end{array}$ & $\begin{array}{l}54 \\
59\end{array}$ & & \\
\hline $\begin{array}{l}1996 \\
\text { Canadians } \\
\text { Albertans }\end{array}$ & $\begin{array}{l}61 \\
53 \\
\end{array}$ & & $\begin{array}{l}36 \\
28\end{array}$ & $\begin{array}{l}51 \\
51\end{array}$ & & \\
\hline $\begin{array}{l}1998 \\
\text { Canadians } \\
\text { Albertans }\end{array}$ & $\begin{array}{l}63 \\
59 \\
\end{array}$ & & $\begin{array}{l}38 \\
34 \\
\end{array}$ & $\begin{array}{l}48 \\
44 \\
\end{array}$ & & \\
\hline $\begin{array}{l}1999 \\
\text { Canadians }\end{array}$ & 67 & & 43 & 54 & 46 & 29 \\
\hline
\end{tabular}

In 1987, 1988 and 1989, Environics again asked Canadians to indicate their level of concern, but in these questions the focus was on Canada's natural resources and not the broader scope of environmental issues. The results are summarized below. 


\begin{tabular}{|l|l|l|l|l|l|}
\hline $\begin{array}{l}\text { "Very } \\
\text { Concerned" } \\
\text { Only }\end{array}$ & $\begin{array}{l}\text { State of } \\
\text { wildlife } \\
\text { population }\end{array}$ & $\begin{array}{l}\text { Supply of } \\
\text { trees }\end{array}$ & $\begin{array}{l}\text { Supply of } \\
\text { prime } \\
\text { agricultural } \\
\text { land }\end{array}$ & $\begin{array}{l}\text { Amount of } \\
\text { wilderness }\end{array}$ & $\begin{array}{l}\text { Supply } \\
\text { of oil } \\
\text { and gas }\end{array}$ \\
\hline $\begin{array}{l}1987 \\
\text { Canadians }\end{array}$ & 65 & 59 & 63 & 49 & 38 \\
\hline 1988 & 51 & 53 & 54 & 36 & 27 \\
Canadians & 56 & 53 & 53 & 48 & 24 \\
\hline 1989 & 56 & 47 & 48 & 50 & 28 \\
\hline
\end{tabular}

In 1998 and 2000, there was a subtle change to the question. Different environmental problems were listed and Canadians were asked how serious they considered them to be, "a very serious problem, not very serious, or not a serious problem at all." The following summarizes the results for issues of interest. (The Environics report included information for 1992, citing Gallup as the source.)

\begin{tabular}{|c|c|c|c|c|c|c|}
\hline $\begin{array}{l}\text { "Very } \\
\text { Serious } \\
\text { Problem" }\end{array}$ & $\begin{array}{l}\text { Water } \\
\text { Pollution }\end{array}$ & $\begin{array}{l}\text { Wilderness } \\
\text { Habitat } \\
\text { Destruction }\end{array}$ & $\begin{array}{l}\text { Depletion } \\
\text { of } \\
\text { Natural } \\
\text { Resources }\end{array}$ & $\begin{array}{l}\text { Species } \\
\text { Loss }\end{array}$ & $\begin{array}{l}\text { Climate } \\
\text { Change }\end{array}$ & $\begin{array}{l}\text { Production, } \\
\text { transportation } \\
\text { and use of oil }\end{array}$ \\
\hline $\begin{array}{l}1992 \\
\text { Canadians }\end{array}$ & 77 & & & 58 & 58 & \\
\hline $\begin{array}{l}1998 \\
\text { Canadians }\end{array}$ & 68 & & 63 & 57 & 46 & 24 \\
\hline $\begin{array}{l}\mathbf{2 0 0 0} \\
\text { Canadians } \\
\text { Albertans }\end{array}$ & $\begin{array}{l}71 \\
66 \\
\end{array}$ & $\begin{array}{l}70 \\
65 \\
\end{array}$ & $\begin{array}{l}68 \\
56 \\
\end{array}$ & $\begin{array}{l}59 \\
55 \\
\end{array}$ & $\begin{array}{l}44 \\
33 \\
\end{array}$ & $\begin{array}{l}29 \\
19 \\
\end{array}$ \\
\hline
\end{tabular}

Canadians have been concerned over the period from 1989 about environmental and natural resource issues. While there have been some shifts over time, there is a fairly consistent level of concern. It could be expected that current issues of the day affected the opinions of Canadians and resulted in some of the changes in the numbers.

\section{Future supply of natural resources}

In 1992, the question was asked in a different manner, focusing on the "future supply of natural resources". Canadians were asked the following question. "When you think of the future supply of the following natural resources of Canada, which one would you say most concerns you?" More than four in ten (Canadians 44\%, Albertans 39\%) identified fresh water as their greatest concern. "This finding is surprising in light of the fact that Canada is considered to have one of the world's largest stocks of fresh water supplies. Clearly, water is a substance of real symbolic value to Canadians and is no longer taken for granted." Much smaller proportions indicated that they were most concerned about 
the other natural resources listed. Canadians were again asked the question in 1995, with some shift in the replies.

\begin{tabular}{|l|l|l|c|c|c|c|c|}
\hline $\begin{array}{l}\text { Greatest } \\
\text { Natural } \\
\text { Resource } \\
\text { Concern }\end{array}$ & $\begin{array}{l}\text { Supply } \\
\text { of } \\
\text { clean } \\
\text { water }\end{array}$ & $\begin{array}{l}\text { Prime } \\
\text { agricultural } \\
\text { land }\end{array}$ & $\begin{array}{l}\text { Supply } \\
\text { of } \\
\text { trees }\end{array}$ & $\begin{array}{l}\text { Wildlife } \\
\text { and } \\
\text { wilderness }\end{array}$ & $\begin{array}{l}\text { Energy } \\
\text { resources }\end{array}$ & $\begin{array}{l}\text { Fish } \\
\text { Stocks }\end{array}$ & $\begin{array}{l}\text { Mineral } \\
\text { Resources }\end{array}$ \\
\hline $\mathbf{1 9 9 2}$ & & 15 & 15 & 9 & 8 & 7 & 1 \\
Canadians & 44 & 16 & 13 & 11 & 14 & 4 & 1 \\
Albertans & 39 & 11 & 12 & 12 & 6 & 17 & 1 \\
\hline $\mathbf{1 9 9 5}$ & & 11 & 16 & 10 & 13 & 1 \\
Canadians & 39 & 11 & 11 & & & & \\
Albertans & 36 & 10 & & & & & \\
\hline
\end{tabular}

\section{Quality of the environment in ten years time}

Finally, Environics asked Canadians in 1990 whether they thought that the quality of the environment would be in a better or worse state in 10 years time. Forty seven percent of Canadians (Albertans 57\%) anticipated that the quality of the environment would be worse and only $31 \%$ (Albertans $25 \%$ ) thought that it would be better. As a follow up in 2002, Canadians were asked if they thought that environmental quality in Canada had improved or worsened over the past ten years. The numbers were split, with $42 \%$ (Albertans $42 \%$ ) indicating they believe conditions have improved somewhat or greatly, and a slight majority at 53\% (Albertans 53\%) believing that it has worsened somewhat or greatly. It could be expected that people's perceptions about the change in the quality of the environment would be a key factor in determining their level of concern about the future and the state of the environment that future generations find. 


\section{WATER QUALITY}

Canadians have been polled about their opinions related to water on a regular basis. The following summarizes information from this polling.

\begin{tabular}{|c|c|c|c|c|c|c|c|}
\hline $\begin{array}{l}\text { Greatest } \\
\text { Water } \\
\text { Concern }\end{array}$ & $\begin{array}{l}\text { Drinking } \\
\text { Water } \\
\text { Safety }\end{array}$ & $\begin{array}{l}\text { Coastal } \\
\text { Lake } \\
\text { River } \\
\text { Quality }\end{array}$ & $\begin{array}{l}\text { Underground } \\
\text { Water Quality }\end{array}$ & $\begin{array}{l}\text { Potential } \\
\text { Shortages }\end{array}$ & $\begin{array}{l}\text { More } \\
\text { than } \\
\text { one }\end{array}$ & None & DK/NA \\
\hline $\begin{array}{l}1989 \\
\text { Canadians } \\
\text { Albertans } \\
\end{array}$ & $\begin{array}{l}38 \\
28 \\
\end{array}$ & $\begin{array}{l}32 \\
36 \\
\end{array}$ & $\begin{array}{l}10 \\
11 \\
\end{array}$ & $\begin{array}{c}6 \\
10 \\
\end{array}$ & $\begin{array}{l}12 \\
13 \\
\end{array}$ & & \\
\hline $\begin{array}{l}1990 \\
\text { Canadians } \\
\text { Albertans } \\
\end{array}$ & $\begin{array}{l}37 \\
31 \\
\end{array}$ & $\begin{array}{l}35 \\
31 \\
\end{array}$ & $\begin{array}{l}13 \\
18 \\
\end{array}$ & $\begin{array}{l}6 \\
6 \\
\end{array}$ & & & \\
\hline $\begin{array}{l}1991 \\
\text { Canadians } \\
\text { Albertans } \\
\end{array}$ & $\begin{array}{l}40 \\
29 \\
\end{array}$ & $\begin{array}{l}29 \\
28 \\
\end{array}$ & $\begin{array}{l}13 \\
18 \\
\end{array}$ & $\begin{array}{c}6 \\
11 \\
\end{array}$ & $\begin{array}{l}9 \\
8 \\
\end{array}$ & & \\
\hline $\begin{array}{l}1992 \\
\text { Canadians }\end{array}$ & 37 & 30 & 13 & 5 & 13 & & \\
\hline $\begin{array}{l}1995 \\
\text { Canadians } \\
\text { Albertans }\end{array}$ & $\begin{array}{l}39 \\
40 \\
\end{array}$ & $\begin{array}{l}30 \\
27 \\
\end{array}$ & $\begin{array}{l}12 \\
15 \\
\end{array}$ & $\begin{array}{l}5 \\
6 \\
\end{array}$ & $\begin{array}{c}10 \\
8 \\
\end{array}$ & & \\
\hline $\begin{array}{l}2000 \text { June) } \\
\text { Canadians } \\
\text { Albertans } \\
\end{array}$ & 43 & 28 & 13 & $\begin{array}{c}7 \\
11 \\
\end{array}$ & $\begin{array}{l}9 \\
8 \\
\end{array}$ & & \\
\hline $\begin{array}{l}\mathbf{2 0 0 0}(\mathbf{O c t}) \\
\text { Canadians } \\
\text { Albertans }\end{array}$ & $\begin{array}{l}46 \\
50\end{array}$ & $\begin{array}{l}24 \\
15\end{array}$ & $\begin{array}{l}18 \\
24\end{array}$ & $\begin{array}{l}6 \\
6\end{array}$ & $\begin{array}{l}3 \\
3\end{array}$ & $\begin{array}{l}1 \\
1\end{array}$ & $\begin{array}{l}1 \\
2\end{array}$ \\
\hline $\begin{array}{l}2002 \\
\text { Canadians } \\
\text { Albertans }\end{array}$ & $\begin{array}{l}44 \\
39\end{array}$ & $\begin{array}{l}24 \\
19\end{array}$ & $\begin{array}{l}16 \\
17\end{array}$ & $\begin{array}{c}9 \\
22\end{array}$ & $\begin{array}{l}5 \\
2\end{array}$ & & \\
\hline
\end{tabular}

The highest proportion of Canadians consistently name drinking water safety as their greatest concern. This could be expected as drinking water quality directly affects all of us and our families. It is also not surprising that the quality of coastal, lake and river water quality would consistently have the next highest proportion of Canadians identifying this as their greatest area of concern. It is interesting to note that, although it is much smaller, there has been a consistent level of concern about potential water shortages. Also, the proportion of those indicating that it is their greatest concern has been often been higher in Alberta. In 2002, there was a significant increase in both the provinces of Saskatchewan and Alberta in the percentage of those responding that they were most concerned about potential water shortages. In Alberta the percentage increased 16 points from $6 \%$ to $22 \%$. Environics concluded that "this rise in concern is probably due to prolonged drought in these regions of late." 


\section{Effects of a major environmental event on the level of public concern}

It is also interesting to note the effects of a major environmental event on the level of public concern. Following the E.coli bacteria contamination of drinking water in Walkerton, Ontario, Environics polled Canadians about their concerns related to water (June 2000). Environics returned to Canadians in the fall of 2000 (Oct. 2000) to determine if public opinion had changed. "Following a twelve point jump from 1995 in the proportion of Ontarians who were most concerned about the safety of drinking water in June 2000, slightly fewer Ontarians (47\%, down four points) now point to the safety of drinking water. Issues and concerns raised by the events in Walkerton may be producing an echo in other parts of the country. All across Canada, the proportions of people pointing to the safety of drinking water as their greatest water concern have increased considerably since June $2000 \ldots$.

\section{AGRICULTURAL LAND}

As with water, Environics has been seeking information on the public's opinions related to agricultural land on a regular basis. Canadians were asked to identify which of a list of factors most concerned them when thinking about agricultural land use. The following summarizes information from this polling.

\begin{tabular}{|l|c|c|c|c|c|}
\hline $\begin{array}{l}\text { Greatest } \\
\text { Agricultural } \\
\text { Land Use Concern }\end{array}$ & $\begin{array}{l}\text { Loss of } \\
\text { Farm Land }\end{array}$ & $\begin{array}{l}\text { Use of } \\
\text { Farm } \\
\text { Chemicals }\end{array}$ & $\begin{array}{l}\text { Loss of Soil } \\
\text { Through } \\
\text { Erosion }\end{array}$ & $\begin{array}{l}\text { Declining Soil } \\
\text { Quality }\end{array}$ & More than one \\
\hline $\mathbf{1 9 8 9}$ & 37 & 31 & 10 & 8 & 14 \\
Canadians & 25 & 26 & 21 & 10 & 10 \\
Albertans & 36 & 33 & 11 & 10 & 8 \\
\hline $\mathbf{1 9 9 0}$ & 23 & 34 & 21 & 11 & 11 \\
Canadians & 34 & 35 & 11 & 13 & 8 \\
Albertans & 16 & 37 & 24 & 11 & 8 \\
\hline $\mathbf{1 9 9 3}$ & 34 & 40 & 9 & 19 & 4 \\
Canadians & 15 & 48 & 12 & 9 & 6 \\
Albertans & 31 & 44 & 9 & 13 & 6 \\
\hline $\mathbf{1 9 9 6}$ & 25 & 44 & 10 & 9 & N/A \\
Canadians & 29 & 45 & 8 & 8 & \\
Albertans & 26 & 45 & 14 & & \\
\hline $\mathbf{1 9 9 7}$ & & & & \\
Canadians & & & & \\
Albertans & & & & \\
\hline $\mathbf{2 0 0 2}$ & & & & & \\
Canadians & & & & \\
Albertans & & & & & \\
\hline
\end{tabular}

It is interesting to note that concern over the use of agricultural chemicals has increased steadily since 1989 . With this shift to greater concern about agricultural chemicals, there has been a drop in the proportion of Canadians identifying the loss of farmland to urban development as their greatest concern. In Alberta, there was a dip in concern about loss of farmland in the mid 1990's, with a return to earlier levels by 2002. 


\section{SUSTAINABLE AGRICULTURE}

Canadians were also asked more specific questions that are of interest. In 1994, Canadians were asked what "sustainable agriculture" meant to them. The highest number of Canadians responded that it meant maintaining our ability to produce food through future generations (Canadians 38\%, Albertans 44\%). A high number of Canadians, 37\% (Albertans 36\%) indicated that the term meant nothing to them or they had no opinion.

Other responses that were given were keeping soil fertile (Canadians $12 \%$, Albertans $7 \%$ ), protecting agricultural land from other uses (Canadians 6\%, Albertans 4\%), land management strategies (Canadians 4\%, Albertans 5\%), limiting the use of farm chemicals (Canadians 4\%, Albertans 1\%) protecting forests (Canadians 2\%, Albertans 1\%) and saving the family farm (Canadians $2 \%$, Albertans 0 ).

In 1995, Canadians were asked two questions. First they were asked which two of five aspects of current agricultural practice would most need to change if agriculture is to be practiced in a sustainable fashion. A total of $74 \%$ replied with chemical use as their first or second mention. Water use and soil use were both identified as a first or second priority by $35 \%$. Twenty eight percent replied packaging use first or second and $23 \%$ energy use.

The following table provides information on the practice that was mentioned first in response to the question. It is interesting to note the significant difference between Canadians in general and Albertans in the responses related to water use practices (significantly lower) and soil use practices (significantly higher).

\begin{tabular}{|l|c|c|}
\hline $\begin{array}{l}\text { Practice Needing to } \\
\text { Change Most - First } \\
\text { Mention }\end{array}$ & Canadians & Albertans \\
\hline Chemical use & 60 & 50 \\
\hline Water use & 12 & 6 \\
\hline Soil use & 11 & 24 \\
\hline Packaging use & 8 & 11 \\
\hline Energy use & 7 & 9 \\
\hline
\end{tabular}

In a related question, Canadians were asked who will most need to change their attitudes and practices to achieve sustainable agriculture. Most of the responsibility is seen to rest with governments and consumers, rather than farmers. Thirty nine percent of Canadians (Albertans 37\%) answered governments, another 23\% (Albertans 21\%) answered consumers. While only $11 \%$ of Canadians identified farmers, a higher percentage of Albertans $(19 \%)$ responded in this way, indicating that they are more likely to place responsibility on farmers.

Canadians were asked in 1997 to read a list of various kinds of farming and identify which has the most negative impact on the environment. Regional differences factored 
into the responses across the country. The following provides the information for Canadians and Albertans.

\begin{tabular}{|l|c|c|}
\hline $\begin{array}{l}\text { Most Negative } \\
\text { Environmental Impact }\end{array}$ & Canadians & Albertans \\
\hline Hog and pig farming & 29 & 12 \\
\hline Cattle and dairy farming & 20 & 17 \\
\hline $\begin{array}{l}\text { Fruit and vegetable } \\
\text { farming }\end{array}$ & 19 & 21 \\
\hline Grain farming & 15 & 27 \\
\hline dk/na & 13 & 17 \\
\hline
\end{tabular}

\section{LOSS OF SPECIES AND BIODIVERSITY}

In 1996, Canadians were told that each year a certain number of plants and animal species become extinct due to changes in their habitat, and were asked about their views. More than seven in ten (Canadians 74\%, Albertans 69\%) agreed with the view that "this species loss has become a very serious global problem, and that we must take urgent action now."

In 1998, Canadians continued to be concerned, with 77\% (Albertans $74 \%$ ) agreeing with the view that species loss has become a very serious global problem. "The findings indicate that biodiversity is a major concern to Canadians and may be the next hot button issue. In fact, other Environmental Monitor findings reinforce this view. We find that there is as much concern about biodiversity as there is about air quality ( $77 \%$ versus $81 \%$ respectively). This finding is quite significant considering the fact that over the past few years there has been increasing media focus on air quality issues and very little on the topic of biodiversity."

In the year 2000, the question was subtly different. Canadians were asked whether species loss is becoming so serious a problem that it requires urgent action or not. A full $82 \%$ of Canadians ( $70 \%$ of Albertans) replied that the problem is becoming very serious. This reflects a steady increase from 1996. "This finding makes it clear that biodiversity is a major concern among Canadians, and it may well constitute a key component of future environmental agendas."

It is interesting to note this high level of concern when species loss is the focus of the question. There was also a steady level of concern regarding species and their habitat expressed by Canadians when asked to rank environmental problems, as noted above. 


\section{LAND USE}

\section{Most important influence on land use decisions}

Canadians have been asked several questions related to land use over the decade. In a broad question Canadians were asked if economic or conservation priorities should most influence land use decisions in Canada today. In 1990, 63\% of Canadians (Albertans $61 \%$ ) answered that conservation should take precedence while only $18 \%$ (Albertans $18 \%$ ) replied that economic considerations should have the most influence. Ten percent (Albertans 9\%) replied that both should have equal influence. When asked again in 1991 , the numbers were very similar with $64 \%$ (Albertans 63\%) indicating that conservation should have priority, $19 \%$ (Albertans 18\%) economic considerations, and $12 \%$ (Albertans $17 \%$ ) both equally. "There is still a very strong consensus that conservation priorities should prevail when determining how land is to be used." It is interesting to note, however, that in 1991, there had been some significant shifts in the numbers in British Columbia. Only $47 \%$ replied that conservation should have priority, $25 \%$ economic considerations and $26 \%$ equal consideration. Environics interpreted these results "not so much that British Columbians are less willing to make the environment a high priority in land use decisions, but rather that they believe that governments and industries must accommodate both priorities simultaneously in order to achieve sustainable development." This is an interesting observation in terms of the evolution of ideas about sustainable development. As noted earlier, there appears to have been a shift from the view that "tradeoffs" between the environment and the economy must be "one versus the other", to a view that the environment and the economy are inextricably linked and that tradeoffs must respect the need to ensure the continued health of both.

When asked again in 1993, Canadians continued to strongly believe that conservation priorities should have the most influence in land use decisions. The numbers remained relatively steady with $61 \%$ (Albertans $55 \%$ ) choosing conservation priorities, $17 \%$ (Albertans 24\%) choosing economic priorities and 17\% (Albertans 18\%) indicating that both should be considered equally. The latter number reflects a continuing rise in the numbers saying that both need to be considered equally. It is interesting to note the shift in the numbers for the province of Alberta. While a majority still replied that conservation priorities should have the most influence, there was a shift from conservation to economic considerations reflected in the responses.

\section{Value of land uses}

An interesting question that provides some insight into the public's perceptions of different land uses was asked in 1993 and 1995. Canadians were asked which uses of land they value most highly and which use of land they felt does the most damage. The following summarizes the responses. 


\begin{tabular}{|l|c|c|l|l|c|c|c|}
\hline $\begin{array}{l}\text { Most } \\
\text { Valued } \\
\text { Use of } \\
\text { Land }\end{array}$ & $\begin{array}{l}\text { Providing } \\
\text { food and } \\
\text { space for } \\
\text { farming }\end{array}$ & $\begin{array}{l}\text { Providing } \\
\text { a home for } \\
\text { wildlife }\end{array}$ & $\begin{array}{l}\text { Providing } \\
\text { space for } \\
\text { housing } \\
\text { and } \\
\text { people }\end{array}$ & $\begin{array}{l}\text { Providing } \\
\text { lumber } \\
\text { and paper } \\
\text { from } \\
\text { forestry }\end{array}$ & $\begin{array}{l}\text { Combin- } \\
\text { ation }\end{array}$ & Other & All \\
\hline $\mathbf{1 9 9 3}$ & & 10 & 4 & 10 & - & 7 \\
Canadians & 43 & 22 & 10 & 6 & 12 & - & 4 \\
Albertans & 32 & 33 & 10 & 4 & 5 & 1 & 5 \\
\hline $\mathbf{1 9 9 6}$ & & 22 & 1 & 8 & 1 & 3 \\
Canadians & 51 & 29 & 8 & 1 & & & \\
Albertans & 49 & & & & &
\end{tabular}

\begin{tabular}{|l|c|c|}
\hline Most Damaging Use of Land (1993) & Canadians & Albertans \\
\hline Forestry & 24 & 35 \\
\hline Waste disposal & 21 & 7 \\
\hline Urban development/ housing & 14 & 18 \\
\hline Agriculture & 7 & 13 \\
\hline Industry/ manufacturing in general & 7 & 6 \\
\hline Mining & 7 & 6 \\
\hline Use of chemicals in general & 2 & 3 \\
\hline Roads and transportation & 2 & - \\
\hline DK/NA & 12 & 11 \\
\hline
\end{tabular}

It is interesting to note that in 1996, there had been an increase of $8 \%$ in the proportion mentioning the agricultural aspects of land use as the most valuable. (It is also noted that there were regional differences in the responses to the most damaging use of land linked to land use controversies in the different provinces. This could be expected to change over time, depending on issues of the day.)

In 1993, Environics concluded the following. "Clearly, there is antagonism to the idea of land being used for housing or forestry, probably because both of these uses are seen as "using up" or destroying the productive qualities of land. On the other hand, the concepts of land as the basis of our agriculture industry and as a home to wildlife - both uses that rely on the ability of land to renew itself - are firmly ensconced in the Canadian consciousness." This is an interesting observation in terms of Canadians perceptions about sustainability. Canadians are clearly concerned about sustainable development. One could expect their opinions about the values of various land uses, or natural resource sectors, to be influenced by the efforts of those resource sectors to achieve sustainability over the long term.

It is interesting to look at another question related to benefits from forests. Environics noted the perception that forestry "uses up or destroys the productive capability of land" (see above). Canadians were asked in 1991, 1993 and 1996 what they believed was the greatest benefit Canadians receive from their forests. The following summarizes the findings. 


\begin{tabular}{|c|c|c|c|c|c|c|c|c|}
\hline $\begin{array}{l}\text { Greatest } \\
\text { Benefit } \\
\text { From } \\
\text { Forests }\end{array}$ & $\begin{array}{l}\text { Effect on } \\
\text { climate/ } \\
\text { air/ oxygen }\end{array}$ & $\begin{array}{l}\text { Source of } \\
\text { resources }\end{array}$ & $\begin{array}{l}\text { Economy/ } \\
\text { economic } \\
\text { growth }\end{array}$ & $\begin{array}{l}\text { Habitat } \\
\text { for } \\
\text { wildlife }\end{array}$ & $\begin{array}{l}\text { Provides jobs/ } \\
\text { employment }\end{array}$ & $\begin{array}{l}\text { Beauty/ } \\
\text { scenery }\end{array}$ & $\begin{array}{l}\text { Place for } \\
\text { recreation/ } \\
\text { relaxation }\end{array}$ & $\begin{array}{l}\text { Other/ } \\
\text { dk/na }\end{array}$ \\
\hline $\begin{array}{l}1991 \\
\text { Canadians } \\
\text { Albertans }\end{array}$ & $\begin{array}{l}29 \\
30\end{array}$ & $\begin{array}{l}22 \\
17\end{array}$ & $\begin{array}{l}8 \\
5\end{array}$ & $\begin{array}{c}6 \\
11\end{array}$ & $\begin{array}{l}7 \\
4\end{array}$ & $\begin{array}{c}9 \\
11\end{array}$ & $\begin{array}{l}4 \\
6\end{array}$ & $\begin{array}{c}5 / 9 \\
5 / 12\end{array}$ \\
\hline $\begin{array}{l}1993 \\
\text { Canadians } \\
\text { Albertans }\end{array}$ & $\begin{array}{l}20 \\
16\end{array}$ & $\begin{array}{l}32 \\
22\end{array}$ & $\begin{array}{c}9 \\
11\end{array}$ & $\begin{array}{l}8 \\
8 \\
\end{array}$ & $\begin{array}{l}5 \\
5\end{array}$ & $\begin{array}{c}8 \\
11\end{array}$ & $\begin{array}{c}8 \\
15\end{array}$ & $\begin{array}{c}3 / 6 \\
- \\
\end{array}$ \\
\hline $\begin{array}{l}1996 \\
\text { Canadians } \\
\text { Albertans }\end{array}$ & $\begin{array}{l}28 \\
27\end{array}$ & $\begin{array}{l}21 \\
17\end{array}$ & $\begin{array}{l}12 \\
16\end{array}$ & $\begin{array}{c}8 \\
10\end{array}$ & $\begin{array}{l}8 \\
4\end{array}$ & $\begin{array}{c}8 \\
15\end{array}$ & $\begin{array}{l}6 \\
3\end{array}$ & $\begin{array}{l}3 / 6 \\
4 / 3\end{array}$ \\
\hline
\end{tabular}

While the numbers reflect that Canadians are divided between those who mention environmental benefits and those who mention economic benefits, the proportion mentioning environmental benefits has increased. It was noted above that one could expect the opinions of Canadians about the values of various land uses, or natural resource sectors, to be influenced by the efforts of those resource sectors to achieve sustainability over the long term. In the case of forestry, will an increase in understanding of this sector result in a change in the way Canadians perceive this land use and its value?

\section{Land use decisions in "built up" or remote areas}

Another question provides insights into concerns related to land use decisions. In 1993, Canadians were asked if they were most concerned with the impact of land use decisions when they affect built-up or urban areas, areas close to built-up areas, or remote wilderness areas. The highest percentage of Canadians, $47 \%$ (Albertans 59\%) replied that they are most concerned with decisions affecting remote wilderness areas.

Noticeably smaller proportions replied that they are most concerned with decisions affecting areas close to built-up areas (Canadians 22\%, Albertans 13\%) or built-up/ urban areas (Canadians 21\%, Albertans 21\%). These findings may provide some insight into how public opinion and levels of concern may evolve with increasing demands on the landscape and increasing conflicts between land uses.

\section{Management of wilderness areas}

Another question provides another perspective. In 1989 and again in 1994, Canadians were asked if they agreed with the following statement, "Canada's wilderness areas can be managed so they support different uses at the same time, such as recreation, wildlife and resource development." In 1989, a full nine in ten Canadians strongly $(52 \%$, Albertans 53\%) or somewhat (37\%, Albertans 36\%) agreed with the statement. In 1994, over eight in ten Canadians continued to strongly (Canadians $45 \%$, Albertans $31 \%$ ) or 
somewhat (Canadians 40\%) agree with the statement. Although the questions above point to a high level of concern about land use decisions in "undeveloped areas" and concerns with some kinds of land use, these results reflect a support for multiple uses of wilderness areas. 


LIBRARY AND ARCHIVES CANADA
Bibliothèque et Archives Canada

33286538600749 